Graduate Institute of International and Development Studies

International Economics Department

Working Paper Series

Working Paper No. HEIDWP21-2015

\title{
The second wave of global liquidity: Why are firms acting like financial intermediaries?
}

\author{
Julian Caballero \\ Inter-American Development Bank \\ Ugo Panizza \\ Andrew Powell \\ Inter-American Development Bank \\ Chemin Eugène-Rigot 2 \\ P.O. Box 136 \\ CH - 1211 Geneva 21 \\ Switzerland
}

The Graduate Institute, Geneva and CEPR

(c) The Authors. All rights reserved. Working Papers describe research in progress by the author(s) and are published to elicit comments and to further debate. No part of this paper may be reproduced without the permission of the authors. 


\title{
The second wave of global liquidity: Why are firms acting like financial intermediaries?
}

\author{
Julian Caballero \\ Inter-American Development Bank
}

\author{
Ugo Panizza \\ The Graduate Institute, Geneva \\ and CEPR
}

\author{
Andrew Powell \\ Inter-American Development Bank
}

October $2015^{*}$

\begin{abstract}
Recent work suggests that non-financial firms have acted like financial intermediaries particularly in emerging economies. We corroborate these findings but then ask why? Our results indicate evidence for carry-trade activities but focused in countries with higher levels of capital controls, particular controls on inflows. We find little evidence for such activities given other potential motives. We posit that this phenomenon is due more to the reaction to low global interest rates and strong capital inflows than to incomplete markets or the retreat of global banks due to impaired balance-sheets or tighter regulations.
\end{abstract}

Keywords: Corporate finance, bond issuance, currency mismatches, carry-trade, capital controls

JEL Codes: E51, F30, F33

\footnotetext{
*Caballero: Research Department, Inter-American Development Bank, 1300 New York Ave NW, Washington DC. Email: JulianC@iadb.org. Panizza: Department of International Economics, The Graduate Institute of International and Development Studies, Maison de la Paix, Case Postale 136 CH1211 Genève 21. Email: Ugo.Panizza@graduateinstitute.ch. Powell (corresponding author): Research Department, Inter-American Development Bank, 1300 New York Ave NW, Washington DC. Email: AndrewP@iadb.org. We would like to thank Jorge Carrera, Claudio Raddatz, Dave Seerattan and participants at the IDB's Network of Central Banks and Finance Ministries of Latin America (Lima, October 2015), and seminars at FGV Sao Paulo, University of St. Gallen, and IDB for comments. We would also like to thank Jaime Ramírez and Daniela Sánchez for excellent research assistance. The views expressed are strictly only those of the authors and do not necessarily reflect the views of the Inter-American Development Bank, its Board of Directors or the countries they represent.
} 


\section{Introduction}

The recent fall in international bank lending and the rise of dollar-denominated international bond issuances, particularly from non-financial corporations based in emerging economies, has been labelled "the second phase of global liquidity" (Shin 2013). Since 2010 international bond issuances by non-financial corporates based in emerging economies has nearly doubled, reaching $\$ 400$ billion by the end of 2014 (Acharya et al. 2015, see also Turner 2013, and IMF 2015).

What did firms do with the proceeds of these bond issues? Bruno and Shin (2015) show that bond issuance has not been used solely for real investment but also to increase cash holdings or other liquid assets. Powell (2014) documents a positive correlation among US dollar issuances of Latin American corporations, corporate deposits in LAC financial systems, and domestic credit. This behavior is consistent with the idea that, by acting as financial intermediaries, non-financial firms have replaced banks as the conduit through which international financial conditions affect domestic liquidity and credit growth in emerging economies.

In this paper we ask why non-financial firms have taken on this role. We suggest that non-financial firms are more likely to act like financial intermediaries in countries with tighter capital controls because non-financial corporates have a comparative advantage in arbitraging capital controls or other regulations that have prevented banks from pursuing what appear to be profitable opportunities.

Low interest rates in advanced economies fueled the fear in emerging economies that strong capital inflows, including carry trade type activities, would led to credit booms and currency appreciation. Some emerging economies responded to this situation with tighter regulations on capital movements. However, non-financial firms may have ways of escaping such controls as they can issue bonds in offshore financial centers and then bring the proceeds of that issuance into the home country via an inter-company loan (which in the balance of payments is normally counted as FDI) and may thus elude capital controls or taxes levied on portfolio flows (see McCauley, Upper, and Villar, 2013).

We test if the presence of capital controls increases the likelihood that non-financial corporations act like financial intermediaries by using data covering 766 non-financial firms located in 18 emerging market countries. We show that these corporations are more likely to hold the resources obtained from foreign currency bond issuances in liquid assets when potential returns from carry trade are high and there are capital account restrictions on inflows. We conjecture that in countries with no or few capital controls, banks remain the main conduit for transmitting global financial conditions to domestic markets but in those countries that have adopted tighter capital controls (especially controls on inflows) this role is at least to some degree being played by corporates.

Our paper is related to several strands of the literature spanning financial depth and corporate financial structure, the role of international banks, and the credit cycle and systemic macroeconomic financial risks. A useful starting point is the corporate finance literature that discusses a "pecking order" for firm financing. This implies that a firm 
would normally use internal sources to finance projects or operations and only seek outside funds when those are exhausted (Myers 2004). An implication is that, unlike financial intermediaries, non-financial corporations' liabilities and liquid financial assets should be negatively correlated (Shin and Zhao 2013). While this is the case for US firms, in emerging economies there is instead a positive correlation between debt and liquid assets (Shin and Zhao 2013).

Bruno and Shin (2014) is perhaps the paper which is closest to ours. This paper also considers the rise in issuance of non-financial corporates and, in analyzing the determinants of issuance, finds evidence in favour of carry trade activities. Our data and methodology in identifying carry trade activities are somewhat different but still we corroborate their findings in this regard. More importantly, we highlight the importance of capital controls and conclude that carry trade activities by non-financial firms are consistent with the presence of regulatory arbitrage. We also test for alternative hypotheses focusing on the retreat of global banks or credit market imperfections but find no evidence in these directions.

A related strand of literature focuses on recent trends in international credit flows. Turner (2013) highlights the shift from bank financing to bond financing, particularly for emerging economies. Chung et al. (2014) document the importance of this trend in terms of overall global liquidity and discuss the potential ramifications for financial stability. Powell (2014) considers the case of four large Latin American economies (Brazil, Chile, Colombia and Mexico) and documents a strong increase in issuance from non-financial firms, particularly in US dollars. ${ }^{1}$ Evidence is presented of an increase in local currency denominated domestic credit (which appears to be financed by corporate deposits) and a deterioration of firms' balance sheets due to a combination of rising dollar amortization schedule and falling earnings ratios. In our paper, we move beyond cross-country correlations and use firm-level data to document when and why non-financial firms act as financial intermediaries.

Our paper also relates to the literature on the links between offshore bond issuances and capital controls Shin (2013) and McCauley, Upper, and Villar (2013) document the recent increase in issuance of Brazilians and Chinese non-financial firms through subsidiaries in offshore financial centres and suggest that issuances through foreign subsidiaries may enable firms to evade capital controls or taxes on certain inflows. Powell (2014) considers this issue in the case of Latin America and shows that while in the case of Brazil issuance on a nationality basis exceeds issuance on a residency basis the opposite is true for Chile. As Chile does not have capital controls while Brazil does, this difference provides prima facia evidence for the potential importance of such controls. In this paper, we test this hypothesis and find that capital controls do indeed increase financial firms' incentives to act as financial intermediaries.

Finally, our paper relates to the recent literature attempting to explain relatively high corporate cash holdings in the US. Bates et al. (2009) for example argue that

\footnotetext{
${ }^{1}$ Rodrigues-Bastos, Kamil, and Sutton (2015) show that this pattern also holds for a larger sample of Latin American economies
} 
precautionary motives may play an important role in order to justify high US firms' cashto-assets ratios. As corporates in emerging economies are operating in an environment of incomplete financial markets, their actions may well be different to those of corporates in advanced economies. For example, large corporates may have better access to capital markets than smaller firms that they have relationships with, such as suppliers. Hence, they might borrow more to be able to pass the proceeds on in the form of direct loans to these firms exploiting the business relationships. In this manner, larger firms may attempt to complete financial markets in environments where financial depth is limited (Petersen and Rajan 1997, Demirgüç-Kunt and Maksimovic 2001, and Fisman and Love 2003, Levine 2004).

This line of argument suggests that there might be a link between the financial structure of large corporates in emerging economies and financial depth. In countries with low levels of financial depth, we may expect to see larger corporates borrowing more to be able to correct such market failures in financial markets. We test whether the incentives of non-financial firms to act as financial intermediaries depend on credit market imperfections (as proxied by financial depth or creditors' rights) and do not find any evidence supporting this hypothesis.

Another literature focusses on the role of international banks. International banks expanded during the 1990's and early 2000's through increased direct lending to clients in other countries, through establishing branches and subsidiaries in host nations, and hence collecting deposits and lending, and through the purchase of securities and structured products issued by foreign entities. ${ }^{2}$ However, the global financial crisis severely hit banks' balance sheets provoking a reduction in leverage and a retreat from international activities such that banks focused more on core assets and provoked a fundamental rethink of regulation. Garcia-Luna and Van Rixtel (2014) provide a description of the retreat of global banks and discuss motivations including impaired balance sheets and regulatory developments. Karam et al. (2014) consider changes in country ratings and their impacts on bank funding.

If the rise of corporates as financial intermediaries is related to the retreat of global banks then we would expect to see a relation with risk. In other words if banks retreated more quickly from countries with lower ratings then perhaps it is in those countries where corporates are now acting more like financial intermediaries. We test this proposition and we also test directly if corporates are behaving like financial intermediaries where international bank claims have fallen the most, but find no evidence supporting these hypotheses.

\footnotetext{
${ }^{2}$ On the expansion and role of foreign banks in emerging economies see for example Goldberg (2002), Martinez-Peria, Powell and Vladkova (2005), and Galindo, Micco and Powell (2005).
} 


\section{Data}

We collected annual data for the period 2000-2014 on firms' balances sheets and bond issuances from two different sources. We focus on a sample composed of the fifty largest listed non-financial and non-foreign owned firms in each of eighteen emerging markets. The baseline analysis includes a total of 766 firms. ${ }^{3}$ Bond issuance by our sample of firms was on a rising trend before the global financial crisis hit, it contracted in 2008 and then boomed over 2009-2013 (Figure 1).

We obtained annual data on firms' liquid financial assets and other balance sheet variables from the Thomson-Reuters Worldscope database and sourced data on bond issuances from Dealogic's DCM database. ${ }^{4}$ Table A2 lists the eighteen markets and gives details of the sample in each. As detailed in the table the sample accounts for over $90 \%$ of the market capitalization in most markets. Note that we are not interested in a representative sample of firms but rather in large firms that are active in capital markets and that have good access to finance and hence may contemplate a variety of different types of market transactions. Our interest is precisely in understanding the behavior of these large firms. We also feel that the large listed firms are likely to have better quality data as their accounts are prepared in a professional manner and audited and studied by outside analysts.

Given different spellings and abbreviations of firm names in each dataset, the data from Worldscope and Dealogic were merged manually, making sure that we were able to either find a match in the issuance data for each listed firm in our sample or that we could assign zero issuance with confidence -because the firm did not have any issuance reported in Dealogic. We matched the two datasets using the names and nationalities of the firms included in the two databases. In a few cases we were unable to identify a clear match based solely on the information contained in the two datasets, so we searched the web for different spellings and abbreviations and were able to match all firms in this way.

As we built our dataset of bond issuance at the parent level, our measure of bond issuance for each firm includes all bonds issued under the name of the firm itself and all

\footnotetext{
${ }^{3}$ We have less than 50 firms in countries where there are less than 50 listed domestically owned nonfinancial corporations.

${ }^{4}$ We downloaded data for all firms listed in the eighteen emerging markets of interest. The universe of firms was identified using Worldscope's constituent lists for all country exchanges in a given country (e.g., firms listed in Sao Paulo or Rio de Janeiro were assigned Brazil as nationality). The largest firms were identified based on market capitalization as of end of 2014. We then used Thomson Reuters' business classification to exclude firms classified as Financials. We used data from Worldscope on foreign ownership of shares to identify firms with foreign majority ownership. Firms with no foreign ownership reported or with less than $50 \%$ of foreign ownership were classified as domestic. After excluding non-financial firms and foreign firms we are left with 803 firms in the eighteen countries of interest; although only 766 firms have data on sales, leverage and other required variables. In some countries, there are less than fifty non-financial, non-foreign firms; yet, in all cases, with the exception of South Korea, the coverage by market capitalization is above $80 \%$. We also use a set of country-level data to describe potential returns from carry trade and capital controls, we describe these when we use them and provide a detailed list of sources in Table A1.
} 
bonds issued through a subsidiary in any part of the world. In our analysis we give equal weight to bonds issued through a subsidiary, perhaps in an offshore financial centre, and bonds issued directly by the parent. The parent's nationality of operations reported in Dealogic was used to assign a particular firm to a particular country. ${ }^{5}$ We constructed measures of bond issuance based on the currency of denomination of the bond and further decomposed foreign currency issuance between hard currencies (USD, EUR, GBP, JPY, and $\mathrm{CHF}$ ) and other currencies. Issuance in hard currencies (FXB) is our key variable of interest.

We complemented the firm-level and bond-level data with country-level data on capital controls, spreads, carry trade profitability, credit ratings, financial depth, creditors' rights and external liabilities. These data and their sources are described in Table A1.

\section{Bond issuance and holdings of liquid financial as- sets}

We start by testing whether non-financial corporations based in emerging markets keep the proceedings of foreign currency bond issuances in cash or other liquid financial assets. We use a specification similar to that in Bruno and Shin (2015). Specifically, we estimate the following model:

$$
\ln \left(\frac{C_{i, c, t}}{S A_{i, c, t}}\right)=F X B_{i, c, t}\left(\beta+\delta \widetilde{S P}_{c, t}\right)+X_{i, c, t} \Gamma+\alpha_{i}+\theta_{c, t}+\varepsilon_{i, c, t}
$$

The dependent variables is the log of liquid financial assets scaled by sales of firm $i$, in country $c$, in year $t$. The explanatory variables are firm-level foreign currency bond issuances $(F X B)$, the demeaned spread $(\widetilde{S P})$ between either the local currency deposit rate or the money market rate (we choose the highest of the two) in country $c$ and borrowing costs in the US for either the sovereign of country $c$ or BAA-rated corporations (we use the lowest of the two), a set of time-variant firm-specific controls (the matrix $X_{i, c, t}$ includes the log of debt over sales, log sales, and leverage), a set of firm fixed effects $\left(\alpha_{i}\right)$, and a set of country-year fixed effects $\left(\theta_{c, t}\right)$. Among other things the country-year fixed effects fully absorbs the main effect of $\widetilde{S P}$.

As we employ the demeaned spread $\left(\widetilde{S P}_{c, t}=S P_{c, t}-\overline{S P}\right)$, in the set-up of Equation (1) $\beta$ captures the marginal effect of bond issuances on holdings of liquid financial assets when $S P_{c, t}=\overline{S P}$ (if we had used $S P_{c, t}$ instead of $\widetilde{S P}_{c, t}, \beta$ would have captured the marginal effect of bond issuances on holdings of liquid financial assets when $S P_{c, t}=0$ ),

\footnotetext{
${ }^{5}$ Dealogic's DCM database reports issuances at the tranche level. We computed a measure of annual issuance in local and foreign currency by parent after downloading all issuances reported in the world for the period 2000-2014. We then collapsed the data using the parent listed in Dealogic. We assign currencies to nationalities based on the currency in use as of end-of-2014. We include in the measure of local currency issuance of bonds indexed and non-indexed to inflation.
} 
and $\delta$ captures how spreads affect the marginal effect of bond issuances on holdings of liquid financial assets. ${ }^{6}$

We use three different measures of foreign currency bond issuances: the log of the dollar value of such issuances; the log of the ratio of foreign currency issuances to sales (this is our baseline); and a dummy variable that takes a value of one if firm $i$ issued a foreign currency bond in year $t^{7}$

When we use our baseline specification (i.e., when $F X B$ is based on the log of the ratio between bond issuances and sales), we are estimating an elasticity and $\beta$ captures the percentage change in the liquid financial assets to sales ratio brought about by a one percent increase in the bond issuance to sale ratio when the spread is at its mean value. The parameter $\delta$, instead, measures by how much a one percentage point increase in the spread affects the elasticity of liquid financial assets to bond issuances.

When we estimate equation (1) without the interactive term (i.e., when we set $\delta=0$ ), we find that foreign bond issuances are always positively correlated with holdings of liquid financial assets (Table 2, columns 1, 4, and 7). Therefore, our results, with an independently constructed dataset, corroborate Bruno and Shin's (2015) finding that in emerging markets non-financial corporations keep a substantial fraction of foreign currency bond proceeds as cash or other liquid financial assets. The point estimate of column 1 suggests that a ten percent increase in bond issuances is associated with an eight percent increase in holdings of liquid financial assets.

When we allow for the correlation between bond issuances and holdings of liquid financial assets to vary with the spread between borrowing costs in the US and return on local currency denominated liquid assets, we find that $\delta$ is always positive (which is prima facie evidence for carry trade activities), but never statistically significant (columns 2, 5 , and 8 of Table 2). The effect, however, is qualitatively large because the point estimates suggest that at the mean one standard deviation increase in spread (4.5 percentage point) would increase the elasticity of holdings of liquid financial assets to bond issuance from 0.8 to 1.2 .

We also interact foreign bond issuances with a dummy variable that takes a value of one when our spread indicator is below the sample median $(L S)$ and a dummy variable that takes value of one when the spread is above the sample median $(H S)$. Columns 3,6 , and 9 of Table 2 show that the coefficient of $F X B \times H S$ is always positive and statistically significant and that the coefficient of $F X B \times L S$ is never statistically significant. This finding is consistent with the result in Bruno and Shin (2015) that, in emerging market countries, bond issuances are significantly correlated with holdings of liquid financial assets when a carry trade indicator is above the median and are not significantly correlated with holdings of liquid financial assets when the carry trade indicator is below the median. The

\footnotetext{
${ }^{6}$ Alternatively, $\delta$ measures how bond issuances affect the marginal effect of spreads on holding of liquid financial assets. Formally, $\delta=\partial\left(\frac{\partial \ln (C / S A)}{\partial F X B}\right) / \partial S P=\partial\left(\frac{\partial \ln (C / S A)}{\partial S P}\right) / \partial F X B$. Note that the marginal effect of spreads on holding of liquid financial assets is absorbed by the country-year fixed effects.

${ }^{7}$ When we take logs, we add one to total bond issuances to retain firm-years with zero issuances. Bruno and Shin (2015) use the same strategy.
} 
effect is also quantitatively important. In column 3, the elasticity of holdings of liquid financial assets to bond issuance in the high spread regime is twice the elasticity in the low spread regime. ${ }^{8}$

So far, we have established that emerging market firms that issue in foreign currency tend to hold more liquid financial assets and that the relationship between bond issuances and holdings of liquid financial assets is increasing in the spread between local deposit rates and the cost of borrowing in the US. We also showed that the effect of spreads is quantitatively large but not statistically significant. In the next section we will explore potential heterogeneity in this relationship. Before doing so, we check if there is something special about foreign currency bonds or whether non-financial corporations always keep a fraction of bond issuances in cash or other liquid financial assets, no matter whether they are issuing in domestic or in foreign currency.

The first two columns of Table 3 estimate the models of the first two columns of Table 2 , but substitute foreign currency bond issuances with domestic currency bond issuances. We find that domestic bond issuances are never significantly correlated with holdings of liquid financial assets. In the last three columns of the table we jointly control for domestic and foreign bond issuances (we use the same definitions of foreign bond issuances of Table 2 ), we find that foreign bond issuances are always significantly correlated with holdings of liquid financial assets and that domestic issuances are never significantly correlated with holdings of liquid financial assets. The coefficients of FXB are also essentially identical to what we found in Table 2.

\section{Carry trade opportunities and capital controls}

Over the period of analysis (2000-2014) there have been significant changes in capital account openness among emerging countries in different directions. Post 2000 there was a general move towards more openness but after the global financial crisis many countries tightened capital controls (see Figure 2 which uses data from Chinn and Ito 2006 and Fernández et al. 2015). Data from Fernández et al. (2015) show that 16 out of the 18 emerging economies studied in this paper introduced at least one tightening measure to capital account transactions over 2008-2013 (a larger sample of 41 emerging economies shows that nearly $80 \%$ of countries introduced at least one tightening measure). Figure 3 illustrates the distribution of capital account openness across countries in 2007 and in 2013. Each plot shows a solid box covering the interquartile range of the capital controls measure, from the lower quartile to the upper quartile and the median. These graphs show a shift in the distribution towards greater capital controls comparing these two years.

When capital account transactions are heavily regulated, it may be difficult or expensive for banks to pursue carry trade activities. However, it may be harder to regulate the transactions of non-financial corporations that can use current account transactions or

\footnotetext{
${ }^{8}$ However, the two coefficients are not significantly different from each other. A fact consistent with our results that $\delta$ is not statistically significant.
} 
inter-company loans (that are normally considered as FDI) to transfer financial resources across countries. In such a setting, non-financial firms may become the channel through which capital inflows take place. If this is the case, we should find that the presence of capital controls amplifies the correlation between foreign bond issuances and holdings of liquid financial assets when there are large differences between domestic and foreign interest rates.

We test if the incentives of non-financial corporation to act akin to a financial intermediary are stronger in the presence of capital controls by estimating the following model:

$$
\begin{aligned}
\ln \left(\frac{C_{i, c, t}}{S A_{i, c, t}}\right)= & F X B_{i, c, t}\left(\beta+\delta \widetilde{S P}_{c, t}+\eta K_{c, t}+\phi\left(\widetilde{S P}_{c, t} K_{c, t}\right)\right)+ \\
& +X_{i, c, t} \Gamma+\alpha_{i}+\theta_{c, t}+\varepsilon_{i, c, t}
\end{aligned}
$$

where $K$ is a continuous measure of capital account openness that ranges between 0 (closed capital account) and 1 (open capital account) and the remaining variables are the same as in Equation (1). Our parameter of interest is $\phi$. A positive value of $\phi$ would suggest that non-financial corporations are more likely to exploit interest rate differentials when the capital account is open. A negative value of $\phi$, instead, would be consistent with Shin and Zhao (2013) and Chung et al.'s (2015) hypothesis that firms use within company loans to elude capital controls (the returns of eluding capital controls are higher because banks, which in general face lower transaction costs, cannot arbitrage interest rate differentials).

Before estimating the model with the triple interaction, we check whether interacting foreign bond issuances with capital account openness alters the results of Table 2 . In columns 1,3 , and 5 of Table 4 we set $\phi=0$ and show that once we control for capital account openness, the main effect of $F X B$ is no longer significant and the interaction effects are not statistically significant.

When we allow for the triple interaction, however, our results change dramatically (columns 2, 4, and 6 of Table 4). The parameter $\delta$ is always positive and statistically significant, indicating that in countries with a closed capital account (i.e., when $K=0$ ), the likelihood that the proceeds of foreign currency bond issuances are kept in cash or other liquid financial assets is increasing in the spread between the local deposit rate and foreign currency borrowing costs (a behavior consistent with the presence of carry trade activities). The effect is also quantitatively large. The point estimates of column 2 suggest that when the spread is at its mean value and the capital account is fully closed a one percent increase in bond issuances is associated with a 0.3 percent increase in holdings of liquid financial assets. A one percentage point increase of the spread, however, would increase the elasticity of holdings of liquid financial assets to 0.8 .

We also find that $\phi$ is always negative, statistically significant and with point estimates close to $-\delta$ (in fact, we cannot reject the hypothesis that $\delta+\phi=0$; we report the test at 
the bottom of Table 4). This finding is consistent with the hypothesis that non-financial corporations do not engage in carry trade activities when they operate in countries with an open capital account $(K=1){ }^{9}$

Panel A of Figure 4 plots how the sensitivity of the relationship between foreign bond issuances and holdings of liquid financial assets to the spread varies with capital account openness (the figure is based on model of column 2, Table 4). We find that $\partial\left(\frac{\partial C a s h}{\partial F X B}\right) / \partial S P$ is positive and statistically significant when $K<0.5$ (the mean value in our sample is 0.51 and the median 0.44 ), the derivative is positive but not statistically significant when $0.5<K<0.7$, and becomes negative (but never statistically significant) when $K>0.7$.

In Table 4, we measured capital account openness using the updated version of the Chinn and Ito (2006) aggregate index. This data source does not contain separate indicators for controls on inflows as opposed to controls on outflows. It is, however, plausible that controls on inflows are more relevant for non-financial firms that are trying to elude capital controls to exploit carry trade opportunities. To test this hypothesis, we use the Fernández et al. (2015) database on capital controls which does contain separate measures for controls on outflows and on inflows.

Table 5 reports the results using our baseline measure of FXB (the results are robust to using the other definitions). In the first column of Table 5, we estimate the same model of column 2, Table 4 by replacing the Chinn and Ito index with the overall measure (inflows and outflows) of capital account openness of Fernández et al. (2015). ${ }^{10}$ The results are similar to those of Table 4 (Panel B of Figure 3, plots the results), but the coefficients are not as precisely estimated as when we use the Chinn and Ito index $(\delta$ and $\phi$ are statistically significant at the ten percent confidence level while they were significant at the one percent confidence level in Table 4).

Next, we use the Fernández et al. (2015) measures of openness to inflows (KI, Column 2 ) and outflows (KO, column 3). We find that the regression that uses controls on inflows yields results which are similar to those obtained for the overall index, but the coefficient are more precisely estimated (they are statistically significant at the 5 percent confidence level). The regression that uses controls on outflows, instead, yields results that are qualitatively similar to the regression that uses the overall index but with statistically insignificant coefficients for $\delta$ and $\phi$.

The fact that openness to inflows and openness to outflows yield different results is particularly telling as the two components of the index are highly correlated (the correlation coefficient is $85 \%$ and a regression of $K I$ over $K O$ yields a coefficient of 0.7 , with a t-statistics of 70 and an R-squared of 0.7). If we include both components in a horserace regression, we still find that openness to inflows decreases the sensitivity of holdings of

\footnotetext{
${ }^{9}$ In Table 4, we follow Shin and Zhao (2013) and scale our variables by sales. Our results are robust to following Bruno and Shin (2015) and scaling our variables by assets (see columns 1-3 of Table A3 in the Appendix)

${ }^{10}$ Note that the original Fernández et al. (2015) index gives higher values for countries with a closed capital account. We rescaled the index such that 1 means open capital account and 0 closed capital account.
} 
liquid financial assets to spreads but openness to outflows does not (column 4). In fact, the two bottom panels of Figure 4 suggest that the effect of openness to outflows goes in the opposite direction. Panel $\mathrm{C}$ plots the coefficient for openness to inflows. We find the usual negative relationship of Panels A and B, but the curve is steeper, and the point at which the coefficient becomes insignificant is higher than in the regressions that use total openness. Panel D, instead, shows that openness to outflows is positively correlated with our measure of carry trade activity, but the coefficient is never statistically significant.

To probe further, we regress the inflow and outflows measures on the overall index of capital controls and use the errors of this regression as measures of controls on inflows and outflows that are orthogonal to overall capital controls (again, we rescale these two measures to range between 0 and 1, with 1 indicating maximum openness). In column 5 of Table 5, we control for both overall capital account openness and for openness to inflows that is orthogonal to overall openness $\left(K I_{R}\right)$, we find that what matters is openness to inflows. In column 6 , we repeat the experiment but now we include openness to outflows $\left(K O_{R}\right)$. We find that the effect goes in the opposite direction, indicating that openness to outflows actually amplifies carry trade activities (this finding is consistent with what we showed in panel D of Figure 4).

Our results are consistent with the idea that firms are unlikely to engage in carry trade activities if they have doubts on their ability to repatriate profits. It may also mean that controls on outflows are more tightly enforced (or enforceable) than controls on inflows.

Next, we substitute our spread variable with a measure of potential carry trade returns. We use the Bloomberg Carry Return Index $(C T I)$. CTI is a proxy of the carry-to-risk ratio obtained by summing the returns from interest rate differentials and exchange rate movements. CTI is often interpreted as an ex-ante measure of the attractiveness of carry trade.

Table 6 shows that high carry trade returns increase the correlation between foreign bond issuances and holdings of liquid financial assets in country-years with a closed capital account but have no effect on the elasticity of holdings of liquid financial assets in countryyears with an open capital account (column 1). We also find that the result holds for openness to inflows (column 2), but does not hold for openness to outflows (column 3) and that the result is robust to running a horserace which includes both openness to inflows and to outflows (column 4).

\section{Alternative explanations: incomplete capital mar- kets and the retreat of banks}

The presence of capital controls is just one of several potential explanations for nonfinancial firms to act as financial intermediaries. Non-financial corporations may also be playing this role because emerging countries have under-developed capital markets or because international banks have retreated. We posit that financial depth and creditor rights are reasonable proxies for the lack of complete financial markets and that banks 
suffering from either impaired balance sheets or increased regulation are likely to retreat more from countries with lower credit ratings on long term foreign currency bonds. ${ }^{11}$ Hence we test for these alternative views by estimating equation (2) replacing capital account openness with a measure of creditor rights, a measure of financial depth, and two indicators for the retreat of global banks, country ratings (risk) and international bank claims.

In column 1 of Table 7, we use the index of creditors' rights compiled by the Doing Business report. We rescale the variable to range between 0 and 1 (1 meaning stronger creditor rights). ${ }^{12}$ We find that creditor rights do not affect the correlation between foreign bond issuance and holdings of liquid financial assets of non-financial corporations (Column 1). Next, we use a standard measure of financial depth (credit to the private sector as a percent of GDP) as a proxy of financial development. ${ }^{13}$ We find that financial depth does not affect the correlation between foreign bond issuances and holdings of liquid financial assets (Column 2). Finally, in columns 3 and 4 we run two horserace regressions that include financial development (creditors' rights in column 3 and financial depth in column 4) and capital account openness (we use controls on inflows, but the results are robust to using overall capital account openness). We find that the effect of capital account openness is robust to controlling for financial depth, while the coefficients have similar magnitude but are not statistically significant when we control for creditors' rights (column 3).

In Table 8 we look at the role of sovereign risk using both Standard and Poor's and Moody's credit ratings (again, we rescale the index to range between 0 and 1 ). Column 1 of Table 8 uses S\&P ratings and shows that credit ratings are not statistically significant in our model. Column 2 includes both credit ratings and capital controls and shows that our baseline results are robust to controlling for credit ratings interactions. Columns 3 and 4 repeat the experiment with Moody's rating and find identical results.

We also test whether our results are driven more directly by changes in the behavior of global banks. Specifically, we augment our model with a variable (which we call BIS) which measures the change in a country's liabilities vis-à-vis BIS reporting banks divided by GDP. We try different measures of liabilities employing the BIS locational banking statistics, namely: (i) total liabilities; (ii) liabilities of non-banks; (iii) total loans; (iv)

\footnotetext{
${ }^{11}$ Powell and Martinez (2008) in particular argue that ratings are actually fairly easy to model as rating agencies give considerable information as to what factors drive their ratings and hence suggest that ratings may be considered a convenient summary of those macroeconomic fundamentals and judgements regarding political and other less quantifiable risks. Cavallo et al (2013) within an errors in measurement type methodology show that sovereign ratings do add value in the sense that market variables are found to respond on average to changes in ratings. These results indicate that ratings may indeed be considered on average as at least a useful summary of fundamentals that drive more market measures of country risk.

${ }^{12}$ As Doing Business data for creditors' rights start in 2005, we use 2005 values for the 2000-2004 period. The results are robust to dropping the 2000-2004 period.

${ }^{13}$ As cash deposits of corporations that borrow abroad may have an impact on the provision of domestic credit, we set FD to be equal to credit to the private sector in the year 2000.
} 
loans of the non-bank sector. We find that none of the BIS variables are statistically significant in our regressions and that there are no qualitative changes in our baseline results (Table 9).

\section{Further robustness checks}

We further check if our results are robust to a series of alternatives specifications and subsamples. First, we split our sample into three different regions: Latin America (6 countries, 261 firms and 2,940 observations), Asia (5 countries, 237 firms and 2,512 observations), and Europe ( 5 countries, 174 firms and 1,726 observations). ${ }^{14}$

Table 9 shows that our results are robust in all sub-regions, but that they are weaker in Europe. This might be due to the fact that in our regressions we use USD borrowing rates, but for European emerging markets the relevant currency is likely to be the Euro. Moreover, three of the countries included in the European subsample (Czech Republic, Hungary, and Poland) are part of the European Union and this may provoke differences with other emerging markets.

To check whether our results are driven by influential observations, we estimate our benchmark regression by dropping one country at a time. Table A4 reports the results for the $F X B \times S P \times K I$ coefficient. It shows that the coefficient is always negative (ranging between -0.01 and -0.03) and statistically significant. We also run a set of placebo regressions (we run 500 regressions that randomly allocate capital controls across countryperiods) and find that the average placebo coefficient is centred at zero and that only 5 percent of the placebo regressions (4.7 percent to be precise) are statistically significant at the 5 percent confidence level. This is exactly what one would expect to find if the coefficient is not statistically significant.

Next, we split the sample in two sub-periods: 2007-2014 and 2000-2006 and find that the results for inflows hold for both sub-periods, but the results for overall capital account openness only hold for 2000-06 (Table A5).

One possible issue with the carry trade interpretation of our results is that, rather than engaging in carry trade activities, non-financial corporations hold the proceedings of bond issuances in liquid financial assets because it takes some time between the moment in which they borrow and the moment in which they need the funds to finance an investment project (of course, it is not obvious why this lag should depend on the spread or why this result should only hold for foreign bond issuances). To check if our results are driven by this possibility, we look at holdings of liquid financial assets one year after bond issuances.

We start by showing that our results are robust to regressing holdings of liquid financial assets at time $t$ on all controls at time $t-1$. The first two columns of Table A6 estimate the model of columns 1-2 of Table 5 but with lagged explanatory variables and find results which are essentially identical to those of Table 5. The last two columns of Table A6

\footnotetext{
${ }^{14}$ We exclude South Africa and Israel which do not belong to any of the geographical regions of Table 7.
} 
measure all explanatory variables at time $t$ with the exception of bond issuances which are measure at time $t-1$. Again, the results are robust to this specification.

It is possible that countries introduce capital controls exactly to limit the type of carry trade activities that we describe in this paper. If this were the case, our estimates would be upward biased. While the use of country-year fixed effects should allay most concerns of reverse causality, we also use two strategies to assess whether our results are robust to controlling for the endogeneity of capital controls.

First, we restrict our sample to 10 years of data and estimate our model for the period 2004-14 by using the level of capital controls in 2003. If changes in capital controls were a reaction to the massive inflows that followed the global financial crisis, using their 2004 values should address any endogeneity concern. The first two columns of Table 11 show that our results are robust to this specification.

Second, we use the results of Table 5 which show that, while controls on inflows are highly correlated with controls on outflows, controls on outflows do not matter when our regressions include controls on inflows. Therefore, we instrument controls on inflows with control on outflows (specifically we instrument $F X B \times K I$ and $F X B \times K I \times S P$ with $F X B \times K O$ and $F X B \times K O \times S P)$. Column 3 of Table 11 shows that in the IV regression the triple interaction coefficient has the right sign but it is no longer statistically significant. This may be due to the loss of efficiency of the IV estimator. In fact, if we limit our sample to Asia and Latin America (the regions for which our results are stronger, see Table 10), the results are also statistically significant in the IV regression (Column 4 Table 11).

\section{Conclusions}

This paper adds to the growing literature considering the increase in issuance of nonfinancial firms, particularly in dollars and especially from emerging economies. There are several potential implications of this phenomenon which is seen as central to the characteristics of the second phase of global liquidity. However, in order to draw the right conclusions and to assess potential risks it is important to understand firms' motives and heterogeneous behaviors.

We first corroborate two results already found in the literature; namely that firms are issuing and some are clearly not using the proceeds solely for real investment but also to maintain liquid financial assets and that they appear to be doing so when the conditions for pursuing carry trade activities are more attractive. This suggests, as others before us have also indicated, that these firms are behaving like financial intermediaries.

However, non-financial firms may be behaving like financial intermediaries for various motives. A benign view would be that they are attempting to correct market failures and hence serving a role in trying to complete incomplete financial markets. However, when we attempt to test such a view considering how such behavior varies with financial depth, or by creditor rights, we do not find any statistically significant results. Alternatively, non-financial firms may be taking the place of global banks that have been retreating due 
to impaired balance sheets or increased regulatory pressure. If this were the case then we would expect some relation to risk and hence we attempt to find a pattern using sovereign credit ratings which are commonly used by banks and by bank regulators to proxy risk, but again we find no statistically significant results. Under this view, we would also expect to find a relation with the change in cross-border banking liabilities but again we find no significant relationship.

A third view is that as a response to low global interest rates and quantitative easing in advanced economies, several emerging economies have imposed or tightened capital controls and that non-financial firms have mechanisms that are not available to banks to evade such controls. We argued that controls on inflows would be particularly relevant in this case. We find strong statistical evidence in favour of the view that non-financial firms are acting like financial intermediaries in countries with relatively high capital controls, particularly where there are controls on capital inflows.

We leave an in-depth discussion of the policy implications of these results for future work (see Acharya et al. 2015 and IMF 2015). Suffice to summarize here however that while our results do not back the view that non-financial firms are attempting to complete incomplete markets nor take on a role left by global banks retreating, they do suggest that firms are attempting to gain from carry trade type activities where capital controls, particularly controls on inflows, are prevalent. In turn this suggests that any evaluation of the efficacy of capital controls should take into account the possibility that they may be evaded through such means. Indeed to the extent that non-financial firms may issue abroad and are able to deposit the funds in the local financial system, evading any capital controls in place, then arguably macro-prudential policies applied on local financial systems may be more effective tools to limit capital inflows and reduce the risks of credit booms. In countries where non-financial firms are behaving in this fashion then it may appear that corporates are highly liquid and hence may be expected to have the resources to repay those external liabilities. However, if the profitability of the carry trade diminishes and firms decide to withdraw their liquidity en mass then this might provoke problems for the domestic financial system. Moreover, the information on whether firms have hedged currency risks remains very partial.

Foreign currency bond issuance in countries with open capital accounts has also been strong but in these cases our results indicate firms have been not been building financial reserves and hence it has been more for real investment. In those countries the risks may then be different, such firms may not be so liquid and risks may relate more to the underlying profitability of the investments. As commodity prices have plummeted and currencies depreciated the risks created by such swings in relative prices may bring large profits or losses; such risks should also then be carefully monitored. 


\section{References}

[1] Acharya, V, S G Cecchetti, J De Gregorio, S Kalemli-Ozcan, P R Lane and U Panizza (2015), "Corporate debt in emerging economies: A threat to financial stability?", Committee for International Policy Reform, Brookings Institution, Washington DC.

[2] Afonso, A., P. Gomes and P. Rother. (2007). "What 'Hides' behind Sovereign Debt Ratings?" Working Paper 711. Frankfurt, Germany: European Central Bank.

[3] Bates, T. W., K. M. Kahle, and R. M. Stulz (2009). Why do us firms hold so much more cash than they used to? The Journal of Finance 64 (5), 1985-2021.

[4] Bruno, V. and Shin, H. S. (2015) "Global dollar credit and carry trades: a firm-level analysis" mimeo American University, May 2015.

[5] Caballero, R., and Krishnamurthy, A. (2003), "Excessive Dollar Debt: Financial Development and Underinsurance," Journal of Finance, Vol. 58, pp. 967-893.

[6] Cavallo, E., A. Powell and R. Rigobon (2013) "Do Credit Rating Agencies Add Value? Evidence From The Sovereign Rating Business," International Journal of Finance \& Economics, John Wiley \& Sons, Ltd., vol. 18(3), pages 240-265, 07.

[7] Chinn, M D and H Ito (2006), "What Matters for Financial Development? Capital Controls, Institutions, and Interactions", Journal of Development Economics, 81(1): 163-192.

[8] Chung,K., J.E. Lee, E. Loukoianova, H.Park and H.S. Shin (2014) "Global Liquidity through the Lens of Monetary Aggregates" IMF working paper, 14/9, January (2014)

[9] Claessens, S. and N. van Horen (2012), "Foreign Banks: Trends, Impact and Financial Stability", International Monetary Fund Working Paper 12/10.

[10] De Haas, R. and N. van Horen (2011), "Running for the Exit: International Banks and Crisis Transmission", DNBWorking Paper, No. 279.

[11] Demirgüç-Kunt, A. and V. Maksimovic, (2001). "Firms as financial intermediaries: Evidence from trade credit data". World Bank mimeo.

[12] Dittmar, A., J. Mahrt-Smith, and H. Servaes (2003). International corporate governance and corporate cash holdings. Journal of Financial and Quantitative analysis 38 (1), $111-134$.

[13] Fernández, A, M W Klein, A Rebucci, M Schindler and M Uribe (2015), "Capital Controls Measures: A New Dataset" NBER Working Paper no. 20,970.

[14] Fisman, R.J. and I. Love. (2003). "Trade credit, financial intermediary development, and industry growth". Journal of Finance 58, 353-374. 
[15] Galindo, A., A Micco and A Powell (2005) "Loyal lenders or fickle financiers: foreign banks in Latin America" IDB working paper, no 529, Dec. 2005.

[16] Garcia-Luna, P. and A. Van Rixtel (2014) "International interbank activity in retreat” BIS Quarterly Review, March 2014.

[17] Goldberg, L. (2002), "When is U.S. Bank Lending to Emerging Markets Volatile?," published in Preventing Currency Crises in Emerging Markets Volume Author/Editor: S. Edwards and J. A. Frankel, editors Volume Publisher: University of Chicago Press, January 2002

[18] Gonzalez-Miranda, M., (2012), "Nonfinancial Firms in Latin America: A Source of Volatility?" IMF Working Paper 12/279, Washington DC.

[19] International Monetary Fund (2015), "Corporate Leverage in Emerging Markets - A Concern?," Chapter 3 in Global Financial Stability Report, Washington, DC.

[20] Karam, P., O. Merrouche, M. Souissi and R. Turk (2014) "The Transmission of Liquidity Shocks: The Role of Internal Capital Markets and Bank Funding Strategies" IMF working paper 14/207, November 2014.

[21] Levine, R., (2005) "Finance and Growth: Theory and Evidence" in the Handbook of Economic Growth Volume 1A, Eds. Philippe Aghion and Steven Durlauf, Elsevier.

[22] Martinez-Peria, S., A. Powell and I. Vladkova (2005) "Banking on Foreigners: The Behavior of International Bank Lending to Latin America, 1985-2000" IMF Staff Papers, 2005, Volume 52, Number 3, December.

[23] McCauley, R., C. Upper and A. Villar (2013) "Emerging market debt securities issuance in offshore centres" in the BIS Quarterly Review, September 2013

[24] Petersen, M.A. and Rajan, R.G. (1997). "Trade credit: Some theories and evidence". Review of Financial Studies 10, 661-692.

[25] Powell, A. (2014), "Global Recovery and Monetary Normalization: Escaping a Chronicle Foretold?" 2014 Latin American and Caribbean Macroeconomic Report, Chapter 4. Inter-American Development Bank, Washington DC.

[26] Powell, A. (2015) "The Labyrinth: How Can Latin America and the Caribbean Navigate the Global Economy" 2015 Latin American and Caribbean Macroeconomic Report, Inter-American Development Bank, Washington DC.

[27] Powell, A. and J. F. Martinez (2008) "On Emerging Economy Sovereign Spreads and Ratings" IDB Working Paper, no. 629 January 2008.

[28] Rajan, R. and L. Zingales, L. (1995), "What Do We Know About Capital Structure? Some Evidence from International Data," Journal of Finance, Vol. 5, pp.1421-60. 
[29] Rodrigues-Bastos, F., H. Kamil, and B. Sutton, (2015), "Corporate Financing Trends and Balance Sheet Risks in Latin America: Taking Stock of "The Bon(d)anza," IMF Working Paper 15/10, Washington DC.

[30] Shin, H.S. and L. Zhao (2013) "Firms as Surrogate Intermediaries: Evidence from Emerging Economies" mimeo Princeton University.

[31] Turner, P. (2013) "The global long-term interest rate, financial risks and policy choices in EMEs", paper for the Inter-American Development Bank Meeting of Chief Economists of Central Banks and Finance Ministries, Washington DC, October 2013 
Table 1: Summary Statistics

\begin{tabular}{lccccc}
\hline \hline & N. Obs & Mean & Std. Dev. & Min & Max \\
\hline & \multicolumn{5}{c}{ Full sample } \\
\hline Total Bond Issuances & 8248 & 117.09 & 693.32 & 0 & 15332 \\
Local Curr. Bond Issuances & 8248 & 71.88 & 497.02 & 0 & 14820 \\
For. Curr. Bond Issuances & 8248 & 45.21 & 369.38 & 0 & 11000 \\
Total Assets & 8248 & 5393.02 & 17298.59 & 3.87 & 408462 \\
Total Debt & 8248 & 1485.29 & 4521.64 & 0 & 112168 \\
\hline \multicolumn{7}{c}{ Firm-years with issuances (13\% of obs.) } \\
\hline Total Bond Issuances & 1041 & 927.69 & 1749.01 & 0.07 & 15332 \\
Total Assets & 1041 & 18890.86 & 38251.78 & 46.49 & 408462 \\
Total Debt & 1041 & 5769.81 & 9928.07 & 12.15 & 112168 \\
\hline & Firm-years with local curr. issuances $(10 \%$ of obs.) \\
\hline Local Currency Bond Issuances & 854 & 694.19 & 1398.51 & 0.07 & 14820 \\
Total Assets & 854 & 18649.13 & 38824.31 & 46.49 & 408462 \\
Total Debt & 854 & 5754.07 & 9702.23 & 12.15 & 94793 \\
\hline & Firm-years with foreign curr. issuances (5\% of obs.) \\
\hline Foreign Currency Bond Issuances & 392 & 951.24 & 1419.07 & 1.5 & 11000 \\
Total Assets & 392 & 35144.74 & 56808.21 & 454.11 & 408462 \\
Total Debt & 392 & 10476.81 & 14239.93 & 21.4 & 112168 \\
\hline \multicolumn{7}{c}{ Macro-level variables (270 country-years) } \\
\hline Spread & 8248 & 1.56 & 4.51 & -2 & 13 \\
Carry trade index & 5730 & 2.1 & 1.39 & 0.67 & 6.79 \\
Cap. Acc. Op. Chinn and Ito & 8248 & 0.51 & 0.29 & 0 & 1 \\
Cap. Acc. Op. Fern. et al. (overall) & 8248 & 0.5 & 0.28 & 0 & 1 \\
Cap. Acc. Op. Fern. et al (inflows) & 8248 & 0.44 & 0.27 & 0 & 1 \\
Cap. Acc. Op. Fern. et al (outflows) & 8248 & 0.56 & 0.32 & 0 & 1 \\
\hline \hline
\end{tabular}




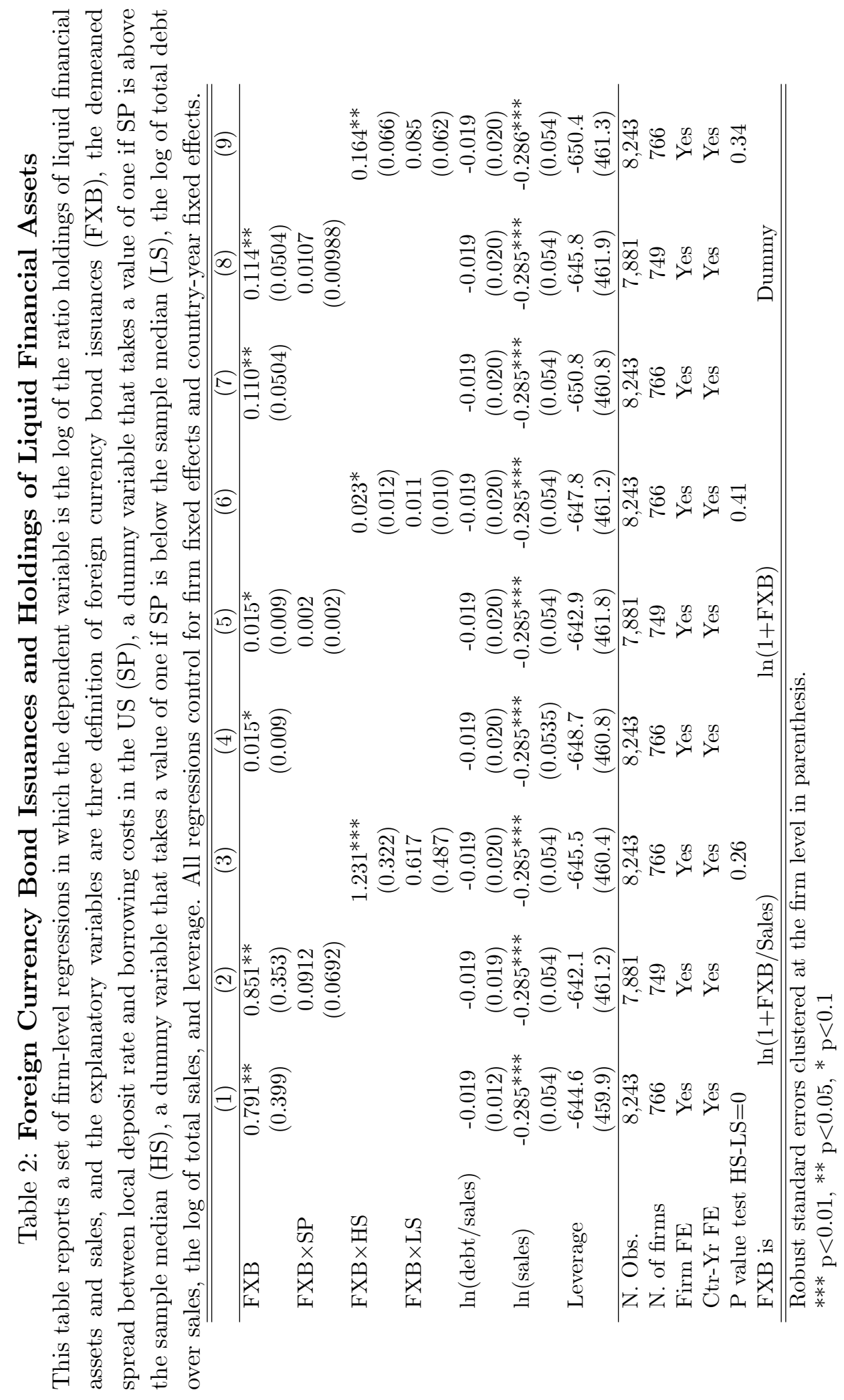




\section{Table 3: Domestic versus Foreign Currency Bonds}

This table reports a set of firm-level regressions in which the dependent variable is the log of the ratio between holdings of liquid financial assets and sales, and the explanatory variables are domestic currency bond issuances (DCB), three definition of foreign currency bond issuances (FXB), the demeaned spread between local deposit rate and borrowing costs in the US (SP), the log of total debt over sales, the log of total sales, and leverage. All regressions control for firm fixed effects and country-year fixed effects.

\begin{tabular}{|c|c|c|c|c|c|}
\hline & (1) & $(2)$ & (3) & (4) & (5) \\
\hline DCB & $\begin{array}{c}0.001 \\
(0.006)\end{array}$ & $\begin{array}{c}0.004 \\
(0.007)\end{array}$ & $\begin{array}{c}0.001 \\
(0.006)\end{array}$ & $\begin{array}{c}0.001 \\
(0.006)\end{array}$ & $\begin{array}{l}0.0004 \\
(0.006)\end{array}$ \\
\hline $\mathrm{DCB} \times \mathrm{SP}$ & & $\begin{array}{c}0.003 \\
(0.002)\end{array}$ & & & \\
\hline FXB & & & $\begin{array}{c}0.790^{* *} \\
(0.399)\end{array}$ & $\begin{array}{l}0.015^{*} \\
(0.008)\end{array}$ & $\begin{array}{l}0.110^{* *} \\
(0.0504)\end{array}$ \\
\hline $\ln ($ debt/sales $)$ & $\begin{array}{l}-0.019 \\
(0.020)\end{array}$ & $\begin{array}{l}-0.019 \\
(0.020)\end{array}$ & $\begin{array}{l}-0.019 \\
(0.020)\end{array}$ & $\begin{array}{l}-0.019 \\
(0.020)\end{array}$ & $\begin{array}{l}-0.019 \\
(0.020)\end{array}$ \\
\hline $\ln$ (sales) & $\begin{array}{c}-0.283^{* * *} \\
(0.053)\end{array}$ & $\begin{array}{c}-0.284^{* * *} \\
(0.053)\end{array}$ & $\begin{array}{c}-0.285^{* * *} \\
(0.054)\end{array}$ & $\begin{array}{c}-0.285^{* * *} \\
(0.054)\end{array}$ & $\begin{array}{c}-0.285^{* * *} \\
(0.054)\end{array}$ \\
\hline Leverage & $\begin{array}{l}-648.4 \\
(460.5)\end{array}$ & $\begin{array}{l}-660.3 \\
(460.7)\end{array}$ & $\begin{array}{l}-645.9 \\
(459.7)\end{array}$ & $\begin{array}{l}-649.4 \\
(460.6)\end{array}$ & $\begin{array}{l}-651.3 \\
(460.7)\end{array}$ \\
\hline N. Obs. & 8,243 & 8,243 & 8,243 & 8,243 & 8,243 \\
\hline N. of firms & 766 & 749 & 766 & 766 & 766 \\
\hline Firm FE & Yes & Yes & Yes & Yes & Yes \\
\hline Ctr-Yr FE & Yes & Yes & Yes & Yes & Yes \\
\hline $\begin{array}{l}\text { DCB is } \\
\text { FXB is }\end{array}$ & & & $\begin{array}{c}\ln (1+\mathrm{DCB} / \text { Sales }) \\
\ln (1+\mathrm{FXB} / \text { Sales })\end{array}$ & $\ln (1+\mathrm{FXB})$ & Dummy \\
\hline
\end{tabular}

Robust standard errors clustered at the firm level in parenthesis. $* * * \mathrm{p}<0.01,{ }^{*} * \mathrm{p}<0.05,{ }^{*} \mathrm{p}<0.1$ 


\section{Table 4: The Role of Capital Account Openness}

This table reports a set of firm-level regressions in which the dependent variable is the log of the ratio between holdings of liquid financial assets and sales, and the explanatory variables are three definition of foreign currency bond issuances (FXB), the demeaned spread between local deposit rate and borrowing costs in the US (SP), the Chinn and Ito index of capital account openness (K). All regressions control for the log of total debt over sales, the log of total sales, leverage, firm fixed effects, and country-year fixed effects.

\begin{tabular}{lcccccc}
\hline \hline & $(1)$ & $(2)$ & $(3)$ & $(4)$ & $(5)$ & $(6)$ \\
\hline FXB & -0.213 & 0.334 & 0.0231 & 0.027 & 0.122 & 0.078 \\
& $(0.667)$ & $(0.655)$ & $(0.019)$ & $(0.017)$ & $(0.111)$ & $(0.115)$ \\
FXB $\times$ SP & 0.097 & $0.514^{* * *}$ & 0.002 & $0.009^{* *}$ & 0.010 & $0.045^{* *}$ \\
& $(0.070)$ & $(0.156)$ & $(0.002)$ & $(0.004)$ & $(0.010)$ & $(0.022)$ \\
FXB $\times \mathrm{K}$ & 2.260 & 1.089 & -0.015 & -0.026 & -0.047 & 0.026 \\
& $(1.160)$ & $(1.086)$ & $(0.037)$ & $(0.033)$ & $(0.205)$ & $(0.213)$ \\
FXB $\times \mathrm{SP} \times \mathrm{K}$ & & $-0.817^{* * *}$ & & $-0.015^{* *}$ & & $-0.076^{*}$ \\
& & $(0.282)$ & & $(0.007)$ & & $(0.041)$ \\
\hline N. Obs. & 7,881 & 7,881 & 7,881 & 7,881 & 7,881 & 7,881 \\
N. of firms & 749 & 749 & 749 & 749 & 749 & 749 \\
\hline Firm FE & Yes & Yes & Yes & Yes & Yes & Yes \\
Ctr-Yr FE & Yes & Yes & Yes & Yes & Yes & Yes \\
\hline$\delta+\phi$ & -0.303 & & -0.006 & & -0.031 \\
p-value & \multicolumn{7}{c}{0.17} & & 0.22 \\
\hline FXB is & $\ln (1+\mathrm{FXB} /$ Sales $)$ & $\ln (1+\mathrm{FXB})$ & Dummy \\
\hline \hline
\end{tabular}

Robust standard errors clustered at the firm level in parenthesis. $* * * \mathrm{p}<0.01,{ }^{* *} \mathrm{p}<0.05, * \mathrm{p}<0.1$ 


\section{Table 5: Different types of Capital Controls}

This table reports a set of firm-level regressions in which the dependent variable is the log of the ratio between holdings of liquid financial assets and sales, and the explanatory variables are foreign currency bond issuances (FXB, defined as $\ln (1+$ issuances/sales $)$ ), the demeaned spread between local deposit rate and borrowing costs in the US (SP), the Fernández et al. index of capital account openness (K), the Fernández et al. index of capital account openness to inflows (KI), the Fernández et al. index of capital account openness to outflows $(\mathrm{KO})$, the residuals of a regression of $\mathrm{KI}$ over $\mathrm{K}\left(K I_{R}\right)$, and the residuals of a regression of $\mathrm{KO}$ over $\mathrm{K}\left(K O_{R}\right)$. All regressions control for the log of total debt over sales, the log of total sales, leverage, firm fixed effects and country-year fixed effects.

\begin{tabular}{|c|c|c|c|c|c|c|}
\hline & (1) & $(2)$ & $(3)$ & $(4)$ & $(5)$ & $(6)$ \\
\hline FXB & $\begin{array}{c}0.332^{* *} \\
(0.151)\end{array}$ & $\begin{array}{c}0.138 \\
(0.167)\end{array}$ & $\begin{array}{c}0.384^{* * * *} \\
(0.145)\end{array}$ & $\begin{array}{l}0.0059 \\
(0.196)\end{array}$ & $\begin{array}{c}-0.604^{*} \\
(0.360)\end{array}$ & $\begin{array}{c}0.962^{* *} \\
(0.410)\end{array}$ \\
\hline $\mathrm{FXB} \times \mathrm{SP}$ & $\begin{array}{l}0.067^{*} \\
(0.034)\end{array}$ & $\begin{array}{c}0.083^{* *} \\
(0.033)\end{array}$ & $\begin{array}{c}0.052 \\
(0.039)\end{array}$ & $\begin{array}{c}0.103^{* * *} \\
(0.036)\end{array}$ & $\begin{array}{c}0.255^{* * *} \\
(0.081)\end{array}$ & $\begin{array}{l}-0.128 \\
(0.126)\end{array}$ \\
\hline $\mathrm{FXB} \times \mathrm{K}$ & $\begin{array}{l}-0.409 \\
(0.267)\end{array}$ & & & & $\begin{array}{l}-0.061 \\
(0.387)\end{array}$ & $\begin{array}{l}-0.076 \\
(0.391)\end{array}$ \\
\hline $\mathrm{FXB} \times \mathrm{SP} \times \mathrm{K}$ & $\begin{array}{c}-0.101^{*} \\
(0.052)\end{array}$ & & & & $\begin{array}{l}-0.049 \\
(0.087)\end{array}$ & $\begin{array}{l}-0.055 \\
(0.088)\end{array}$ \\
\hline $\mathrm{FXB} \times \mathrm{KI}$ & & $\begin{array}{c}0.006 \\
(0.285)\end{array}$ & & $\begin{array}{c}0.977^{* *} \\
(0.457)\end{array}$ & & \\
\hline $\mathrm{FXB} \times \mathrm{SP} \times \mathrm{KI}$ & & $\begin{array}{c}-0.1111^{* *} \\
(0.048)\end{array}$ & & $\begin{array}{c}-0.276^{* * *} \\
(0.099)\end{array}$ & & \\
\hline $\mathrm{FXB} \times \mathrm{KO}$ & & & $\begin{array}{c}-0.583^{* *} \\
(0.278)\end{array}$ & $\begin{array}{c}-0.849^{* *} \\
(0.416)\end{array}$ & & \\
\hline $\mathrm{FXB} \times \mathrm{SP} \times \mathrm{KO}$ & & & $\begin{array}{l}-0.094 \\
(0.074)\end{array}$ & $\begin{array}{c}0.174 \\
(0.135)\end{array}$ & & \\
\hline $\mathrm{FXB} \times K I_{R}$ & & & & & $\begin{array}{c}1.551^{* *} \\
(0.664)\end{array}$ & \\
\hline $\mathrm{FXB} \times \mathrm{SP} \times K I_{R}$ & & & & & $\begin{array}{c}-0.390^{* * *} \\
(0.192)\end{array}$ & \\
\hline $\mathrm{FXB} \times K O_{R}$ & & & & & & $\begin{array}{c}-1.566^{* *} \\
(0.672)\end{array}$ \\
\hline $\mathrm{FXB} \times \mathrm{SP} \times K O_{R}$ & & & & & & $\begin{array}{l}0.379^{*} \\
(0.193)\end{array}$ \\
\hline N. Obs & 8,241 & 8,241 & 8,241 & 8,241 & 8,241 & 8,241 \\
\hline N. Firms & 766 & 766 & 766 & 766 & 766 & 766 \\
\hline Firm FE & Yes & Yes & Yes & Yes & Yes & Yes \\
\hline Country-Yr FE & Yes & Yes & Yes & Yes & Yes & Yes \\
\hline
\end{tabular}

Robust standard errors clustered at the firm level in parenthesis.

$* * * \mathrm{p}<0.01,{ }^{*} * \mathrm{p}<0.05,{ }^{*} \mathrm{p}<0.1$ 


\section{Table 6: Carry trade index instead of spread}

This table reports a set of firm-level regressions in which the dependent variable is the log of the ratio between holdings of liquid financial assets and sales, and the explanatory variables are foreign currency bond issuances (FXB, defined as $\ln (1+$ issuances/sales $))$, the demeaned value of the Bloomberg index of carry trade return (CTI), the Fernández et al. index of capital account openness (K), the Fernández et al. index of capital account openness to inflows (KI), the Fernández et al. index of capital account openness to outflows (KO). All regressions control for the log of total debt over sales, the log of total sales, leverage, firm fixed effects and country-year fixed effects.

\begin{tabular}{|c|c|c|c|c|}
\hline & $(1)$ & $(2)$ & $(3)$ & $(4)$ \\
\hline FXB & -0.250 & 0.548 & 0.173 & 0.617 \\
\hline & $(0.613)$ & $(0.548)$ & $(0.373)$ & $(0.516)$ \\
\hline $\mathrm{FXB} \times \mathrm{CTI}$ & $1.173^{* *}$ & $\begin{array}{l}1.103^{* *} \\
(0.457)\end{array}$ & $\begin{array}{l}-0.0818 \\
(0.308)\end{array}$ & $\begin{array}{r}0.978^{* *} \\
(0.481)\end{array}$ \\
\hline $\mathrm{FXB} \times \mathrm{K}$ & $\begin{array}{l}1.749 \\
(1.092)\end{array}$ & & & \\
\hline $\mathrm{FXB} \times \mathrm{CTI} \times \mathrm{K}$ & $\begin{array}{c}-3.402^{\text {*** }} \\
(1.290)\end{array}$ & & & \\
\hline $\mathrm{FXB} \times \mathrm{KI}$ & & $\begin{array}{c}0.535 \\
(1.124)\end{array}$ & & $\begin{array}{l}-0.641 \\
(1.230)\end{array}$ \\
\hline $\mathrm{FXB} \times \mathrm{CTI} \times \mathrm{KI}$ & & $\begin{array}{c}-2.756^{* *} \\
(1.083)\end{array}$ & & $\begin{array}{c}-2.673^{* * *} \\
(0.852)\end{array}$ \\
\hline $\mathrm{FXB} \times \mathrm{KO}$ & & & $\begin{array}{c}1.941^{* * * *} \\
(0.720)\end{array}$ & $\begin{array}{l}1.719^{*} \\
(0.946)\end{array}$ \\
\hline $\mathrm{FXB} \times \mathrm{CTI} \times \mathrm{KO}$ & & & $\begin{array}{l}-0.290 \\
(1.139)\end{array}$ & $\begin{array}{c}0.576 \\
(1.773)\end{array}$ \\
\hline N. Obs. & 5,587 & 5,587 & 5,587 & 5,587 \\
\hline N. of Firms & 523 & 523 & 523 & 523 \\
\hline Firm FE & Yes & Yes & Yes & Yes \\
\hline Country-year FE & Yes & Yes & Yes & Yes \\
\hline
\end{tabular}

Robust standard errors clustered at the firm level in parenthesis. ${ }^{* * *} \mathrm{p}<0.01,{ }^{* *} \mathrm{p}<0.05,{ }^{*} \mathrm{p}<0.1$ 


\section{Table 7: The role of Creditors' rights and Financial Depth}

This table reports a set of firm-level regressions in which the dependent variable is the log of the ratio between holdings of liquid financial assets and sales, and the explanatory variables are foreign currency bond issuances (FXB, defined as $\ln (1+$ issuances/sales $))$, the demeaned spread between local deposit rate and borrowing costs in the US (SP), The doing business index of creditor rights $(\mathrm{CR}$, the index rescaled to range between 0 and 1 , with 1 indicating stronger creditors' rights), a measure of financial depth (FD is credit to the private sector over GDP in the year 2000), the Fernández et al. index of capital account openness to inflows (KI). All regressions control for the log of total debt over sales, the log of total sales, leverage, firm fixed effects and country-year fixed effects.

\begin{tabular}{lcccc}
\hline \hline & $(1)$ & $(2)$ & $(3)$ & $(4)$ \\
\hline $\mathrm{FXB}$ & 0.230 & 0.622 & 0.420 & 0.646 \\
& $(2.034)$ & $(0.824)$ & $(2.046)$ & $(0.932)$ \\
$\mathrm{FXB} \times \mathrm{SP}$ & 0.409 & 0.123 & 0.834 & $0.668^{* *}$ \\
& $(0.543)$ & $(0.282)$ & $(0.569)$ & $(0.310)$ \\
$\mathrm{FXB} \times \mathrm{CR}$ & 0.170 & & 0.049 & \\
& $(0.432)$ & & $(0.528)$ & \\
$\mathrm{FXB} \times \mathrm{CR} \times \mathrm{SP}$ & -0.040 & & -0.027 & \\
& $(0.129)$ & & $(0.130)$ & \\
$\mathrm{FXB} \times \mathrm{FD}$ & & -0.089 & & 0.308 \\
& & $(0.679)$ & & $(0.710)$ \\
$\mathrm{FXB} \times \mathrm{FD} \times \mathrm{SP}$ & & 0.008 & & 0.039 \\
& & $(0.216)$ & & $(0.225)$ \\
$\mathrm{FXB} \times \mathrm{KI}$ & & & 0.276 & 1.005 \\
& & & $(2.411)$ & $(1.125)$ \\
$\mathrm{FXB} \times \mathrm{KI} \times \mathrm{SP}$ & & & -1.034 & $-0.786^{* * *}$ \\
& & & $(0.608)$ & $(0.202)$ \\
\hline $\mathrm{N} . \mathrm{Obs}$. & 5,831 & 6,621 & 5,831 & 6,621 \\
$\mathrm{~N}$. of Firms & 648 & 622 & 648 & 622 \\
\hline Firm FE & Yes & Yes & Yes & Yes \\
Country-year FE & Yes & Yes & Yes & Yes \\
\hline \hline
\end{tabular}

Robust standard errors clustered at the firm level in parenthesis. *** $\mathrm{p}<0.01, * * \mathrm{p}<0.05, * \mathrm{p}<0.1$ 


\section{Table 8: Sovereign Risk}

This table reports a set of firm-level regressions in which the dependent variable is the log of the ratio between holdings of liquid financial assets and sales, and the explanatory variables are foreign currency bond issuances (FXB, defined as $\ln (1+$ issuances/sales)), the demeaned spread between local deposit rate and borrowing costs in the US (SP), numerical credit rating (RATING, the index is rescaled to range between 0 and 1 , with 1 indicating AAA), the Fernández et al. index of capital account openness to inflows (KI). All regressions control for the log of total debt over sales, the log of total sales, leverage, firm fixed effects and country-year fixed effects.

\begin{tabular}{lcccc}
\hline \hline & $(1)$ & $(2)$ & $(3)$ & $(4)$ \\
\hline FXB & -0.478 & -0.199 & -0.056 & 0.522 \\
& $(1.120)$ & $(1.289)$ & $(1.145)$ & $(1.457)$ \\
FXB $\times$ SP & 0.371 & $0.901^{* * *}$ & $0.373^{*}$ & $1.067^{* * *}$ \\
& $(0.246)$ & $(0.309)$ & $(0.207)$ & $(0.335)$ \\
FXB $\times$ RATING & 2.438 & 1.378 & 1.726 & 0.437 \\
& $(2.063)$ & $(2.239)$ & $(2.032)$ & $(2.397)$ \\
FXB $\times$ RATING $\times$ SP & -0.564 & -0.743 & -0.590 & $-0.964^{*}$ \\
& $(0.560)$ & $(0.534)$ & $(0.484)$ & $(0.515)$ \\
FXB $\times$ KI & & 0.576 & & 0.247 \\
& & $(0.878)$ & & $(0.906)$ \\
FXB $\times$ KI $\times$ SP & & $-0.705^{* * *}$ & & $-0.797^{* * *}$ \\
& & $(0.194)$ & & $(0.241)$ \\
\hline N. Obs. & 7,622 & 7,622 & 7,310 & 7,310 \\
N. of Firms & 716 & 716 & 716 & 716 \\
\hline Firm FE & Yes & Yes & Yes & Yes \\
Country year FE & Yes & Yes & Yes & Yes \\
\hline RATING is & \multicolumn{3}{c}{ S\&P } & \multicolumn{2}{c}{ Moody's } \\
\hline \hline
\end{tabular}

Robust standard errors clustered at the firm level in parenthesis. *** $\mathrm{p}<0.01, * * \mathrm{p}<0.05,{ }^{*} \mathrm{p}<0.1$ 


\section{Table 9: Country Liabilities to BIS Reporting Banks}

This table reports a set of firm-level regressions in which the dependent variable is the log of the ratio between holdings of liquid financial assets and sales, and the explanatory variables are foreign currency bond issuances (FXB, defined as $\ln (1+$ issuances/sales $)$ ), the demeaned spread between local deposit rate and borrowing costs in the US (SP), the Fernández et al. (2015) index of capital account openness to inflows (KI), and the change in the ratio of liabilities versus BIS reporting banks and GDP (BIS). We use four measure for BIS: total liabilities versus BIS reporting banks (column 1); total liabilities of the non-bank sector versus BIS reporting banks (column 2); total loans with BIS reporting banks (column 3); total loans with BIS reporting bank of the non-bank sector (column 4). All regressions control for the log of total debt over sales, the log of total sales, leverage, firm fixed effects and country-year fixed effects.

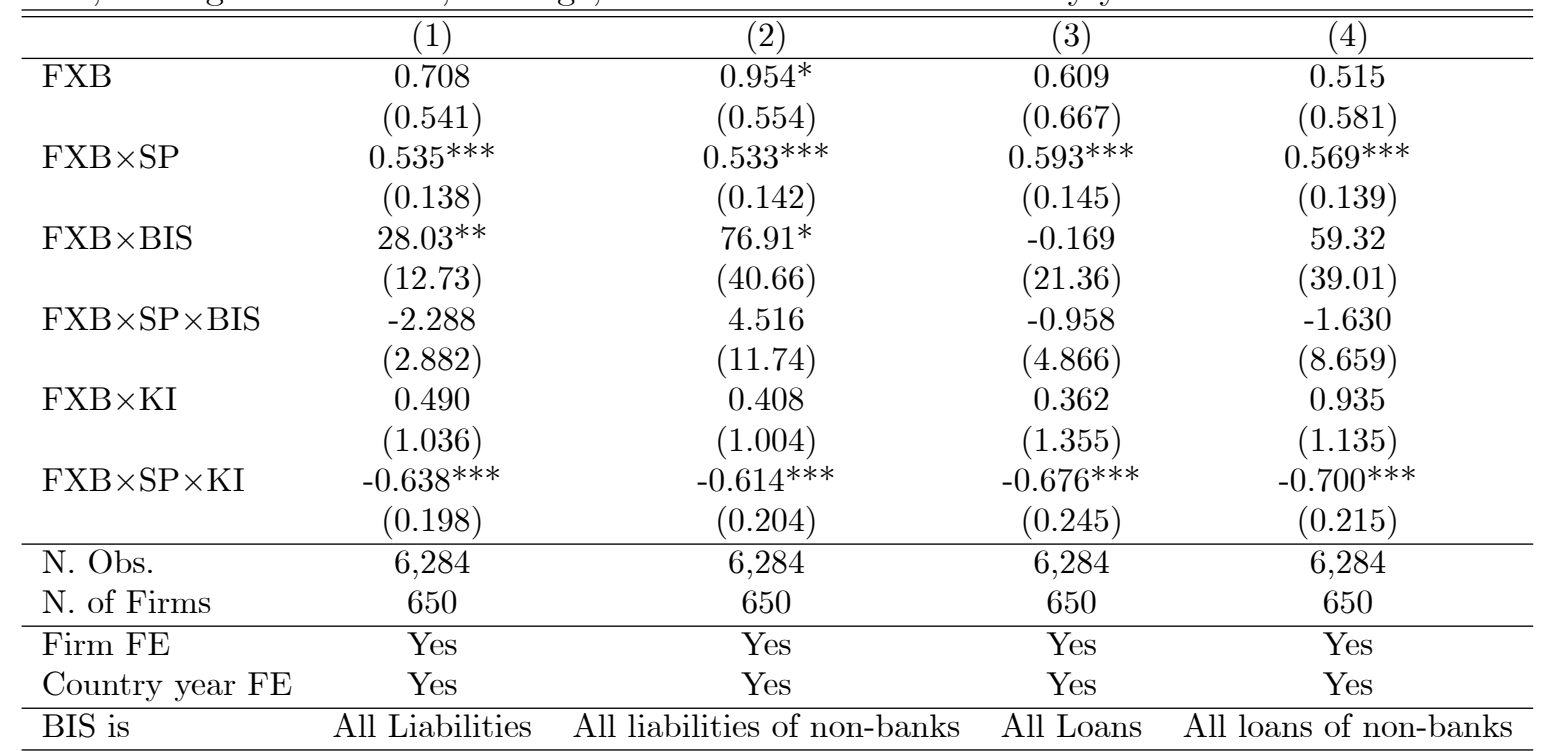

Robust standard errors clustered at the firm level in parenthesis.

$* * * \mathrm{p}<0.01, * * \mathrm{p}<0.05, * \mathrm{p}<0.1$ 
Table 10: Different Regions

This table reports a set of firm-level regressions in which the dependent variable is the log of the ratio between holdings of liquid financial assets and sales, and the explanatory variables are foreign currency bond issuances (FXB, defined as $\ln (1+$ bond issuances/sales $)$ ), the demeaned spread between local deposit rate and borrowing costs in the US (SP), the Fernández et al. index of capital account to inflows (KI). All regressions control for the log of total debt over sales, the log of total sales, leverage, firm fixed effects and country-year fixed effects. Column 1 focuses on Latin America, Column 2 on Asia and Column 3 on Emerging Europe.

\begin{tabular}{lccc}
\hline \hline & $(1)$ & $(2)$ & $(3)$ \\
\hline FXB & $-0.061^{* *}$ & $0.010^{* * *}$ & 0.044 \\
& $(0.027)$ & $(0.028)$ & $(0.068)$ \\
FXB $\times$ SP & $0.023^{* * *}$ & $0.0120^{* *}$ & 0.021 \\
& $(0.004)$ & $(0.008)$ & $(0.015)$ \\
FXB $\times$ KI & $0.138^{* * *}$ & $-0.133^{* *}$ & -0.019 \\
& $(0.047)$ & $(0.064)$ & $(0.113)$ \\
FXB $\times$ SP $\times$ KI & $-0.031^{* * *}$ & $-0.026^{*}$ & $-0.056^{* *}$ \\
& $(0.007)$ & $(0.016)$ & $(0.028)$ \\
\hline N. Obs. & 2,940 & 2,512 & 1,726 \\
N. of Firms & 261 & 237 & 174 \\
\hline Firm FE & Yes & Yes & Yes \\
Country year FE & Yes & Yes & Yes \\
\hline Region & LAC & ASIA & EUROPE \\
\hline \hline
\end{tabular}

Robust standard errors clustered at the firm level in parenthesis. ${ }^{* * *} \mathrm{p}<0.01,{ }^{* *} \mathrm{p}<0.05,{ }^{*} \mathrm{p}<0.1$ 


\section{Table 11: Endogeneity}

This table reports a set of firm-level regressions in which the dependent variable is the log of the ratio between holdings of liquid financial assets and sales, and the explanatory variables are foreign currency bond issuances (FXB, defined as $\ln (1+$ issuances/sales)), the demeaned spread between local deposit rate and borrowing costs in the US (SP), the Fernández et al. index of capital account openness (K) in 2003 (column 1), the Fernández et al. index of capital account openness to inflows (K) in 2003 (column 2), the time varying Fernández et al. index of capital account openness to inflows $(\mathrm{K})$ instrumented with openness to outflows. All regressions control for the log of total debt over sales, the log of total sales, leverage, firm fixed effects and country-year fixed effects.

\begin{tabular}{lcccc}
\hline \hline & $(1)$ & $(2)$ & $(3)$ & $(4)$ \\
\hline FXB & -0.099 & 0.046 & 0.556 & 0.469 \\
FXB $\times \mathrm{SP}$ & $(0.583)$ & $(0.616)$ & $(0.854)$ & $(0.800)$ \\
& $0.420^{* *}$ & $0.497^{* *}$ & $0.261^{*}$ & $0.384^{* *}$ \\
FXB $\times \mathrm{K}$ & $(0.198)$ & $(0.197)$ & $(0.137)$ & $(0.196)$ \\
& 0.342 & 0.206 & -1.239 & -0.835 \\
FXB $\times \mathrm{K} \times \mathrm{SPR}$ & $(1.218)$ & $(1.093)$ & $(1.860)$ & $(1.836)$ \\
& $-0.732^{* *}$ & $-0.693^{* * *}$ & -0.471 & $-0.670^{* *}$ \\
\hline Observations & $(0.342)$ & $(0.238)$ & $(0.360)$ & $(0.320)$ \\
Number of firms & 6,685 & 6,685 & 6,851 & 4,531 \\
Firm FE & 750 & 750 & 735 & 474 \\
Country-year FE & Yes & Yes & Yes & Yes \\
Capital account openness & Yes & Yes & Yes & $K I_{t}$ \\
Country-year FE & $K_{2003}$ & $K I_{2003}$ & $K I_{t}$ & Yes \\
\hline Estimation & Yes & Yes & Yes & IV \\
Instrument & OLS & OLS & IV & $K O_{t}$ \\
Estimation period & & & $K O_{t}$ & $2000-13$ \\
\hline Sample & $2003-13$ & $2003-13$ & $2000-13$ & Asia and Latin America \\
\hline \hline
\end{tabular}

Robust standard errors clustered at the firm level in parenthesis.

$* * * \mathrm{p}<0.01, * * \mathrm{p}<0.05, * \mathrm{p}<0.1$ 
Figure 1: Domestic and Foreign Currency Bond Issuances.

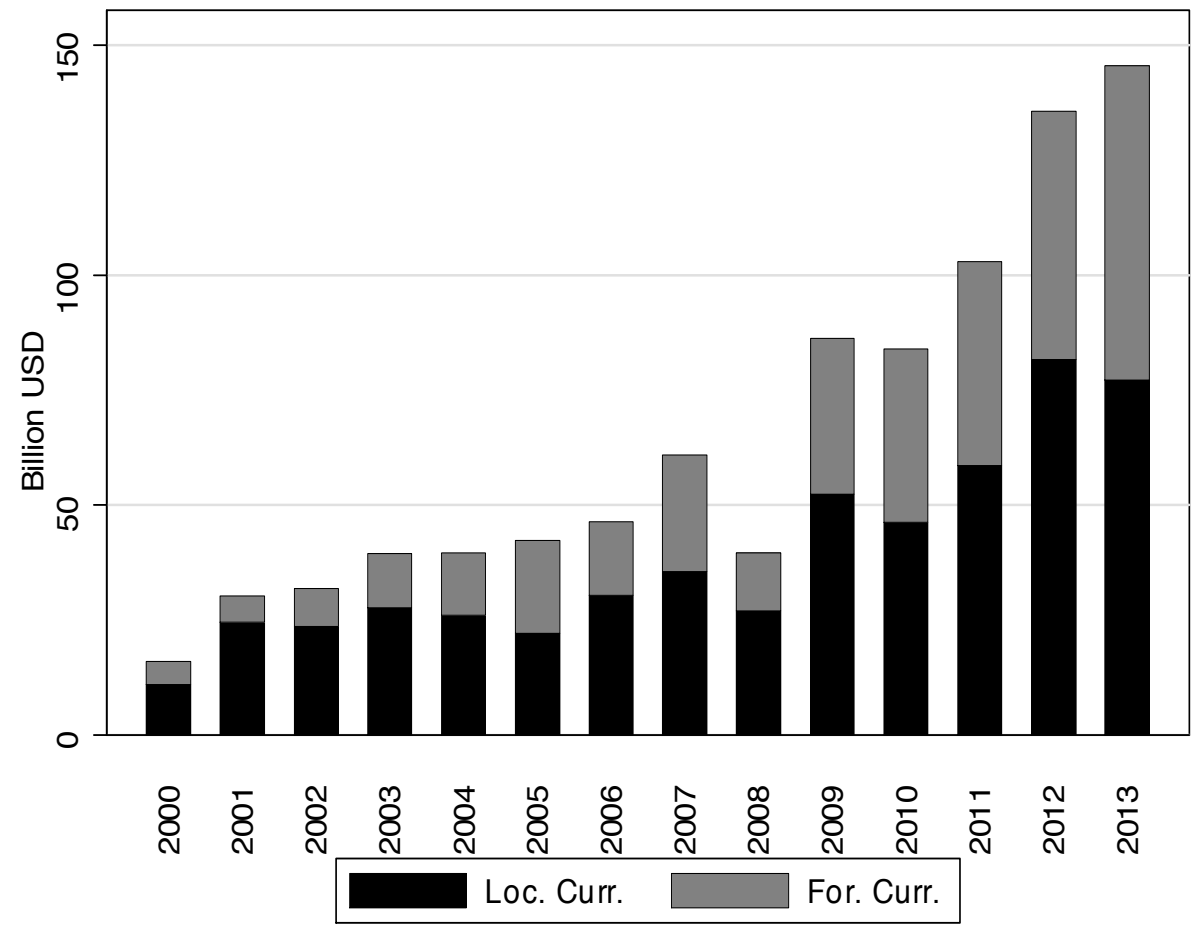


Figure 2: Evolution of Capital Account Openness. This figure plots the evolution of different indexes of capital account openness for the sample of countries included in the regressions of this paper. In all graphs the solid line plots the median value of the index and the dashed lines plot the top and bottom 20th percentile of the index. Panel A uses the Chinn and Ito Index, Panel B the aggregate index of Fernandez et al., Panel $\mathrm{C}$ the Fernandez et al. index of openness to inflows, and Panel D the Fernandez et al. index of openness to outflows.
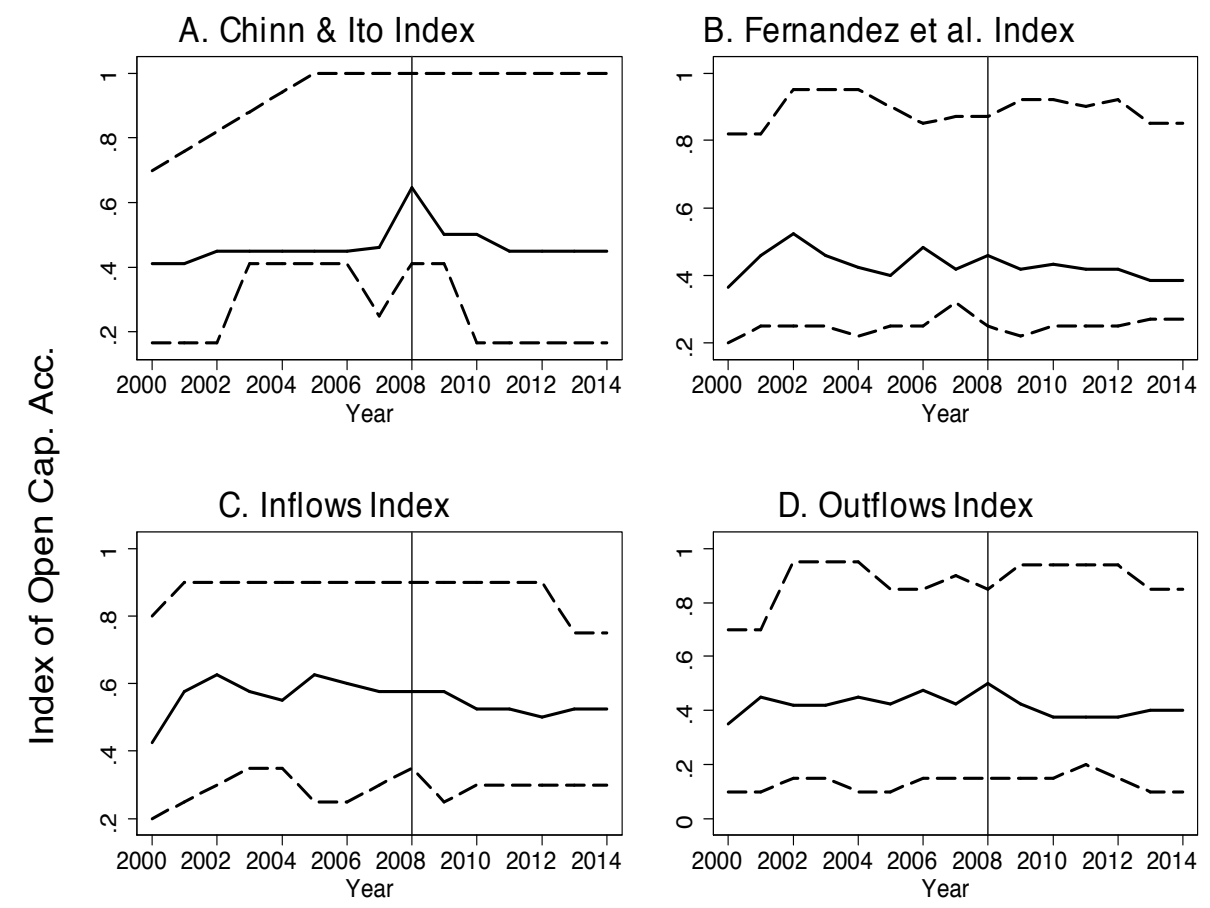
Figure 3: Distribution of Capital Account Opennes across Countries in 2007 and in 2013. This figure plots the evolution of different indexes of capital account openness for the sample of countries included in the regressions of this paper. The box plots the interquartile range and the median and the whiskers the upper and lower adjacent values. Panel A uses the Chinn and Ito Index, Panel B the aggregate index of Fernandez et al., Panel $\mathrm{C}$ the Fernandez et al. index of openness to inflows, and Panel D the Fernandez et al. index of openness to outflows.
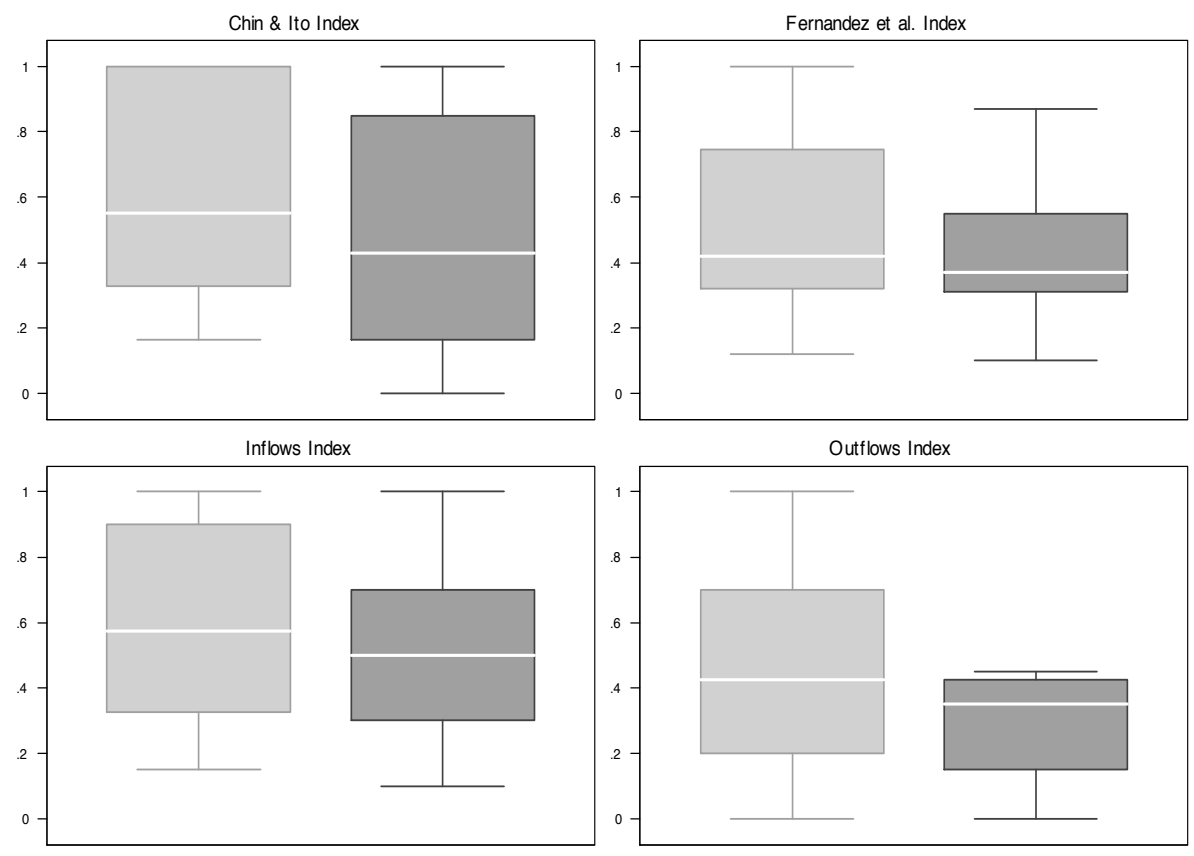

2007

2013 
Figure 4: Marginal Effect. This figure plots how the sensitivity of the relationship between foreign bond issuances and holding of liquid financial assets to our spread variable varies with capital account openness. The solid line plots the main effect and the dashed lines are 95 percent confidence intervals. Panel $\mathrm{A}$ is uses the model of column 2, Table 4; Panel B uses the model of column 1, Table 5; and panels $\mathrm{C}$ and $\mathrm{D}$ use the model of column 4, Table 5.
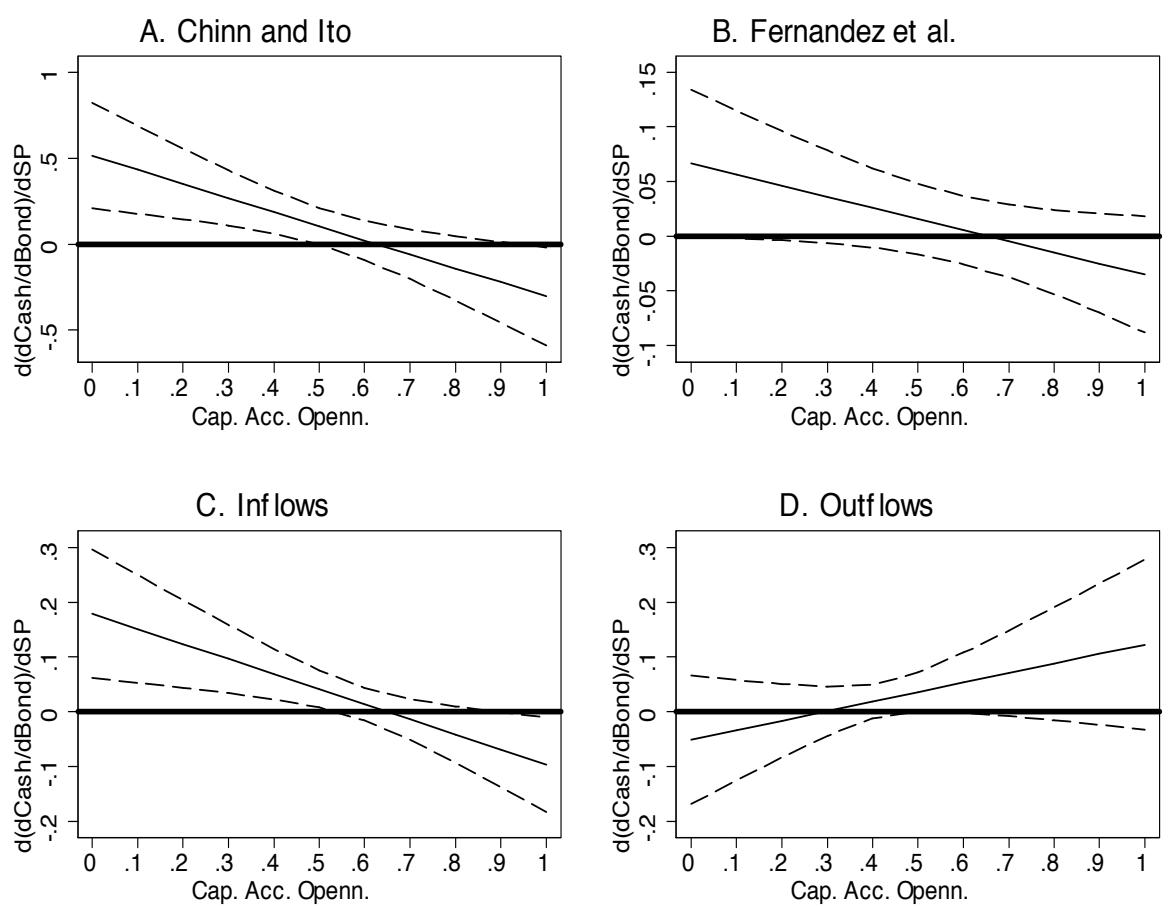


\section{Appendix}

Table A1: Data Description and Sources

\begin{tabular}{|c|c|}
\hline Variable & Description and Sources \\
\hline $\ln (\mathrm{C} / \mathrm{SA})$ & Logarithm of liquid financial assets over sales for firm i, country c, year t. Source: Worldscope. \\
\hline $\ln ($ debt/sales $)$ & Logarithm of debt over sales for firm i, country c, year t. Source: Worldscope. \\
\hline $\ln ($ sales $)$ & Logarithm of sales for firm i, country c, year t (sales are in millions or USD). Source: Worldscope. \\
\hline Leverage & Debt over assets for firm i, country c, year t. Source: Worldscope. \\
\hline FXB & $\begin{array}{l}\text { Total foreign currency bond issuance for firm i, country c, year t (millions USD). Source: Own } \\
\text { calculations based on bond-level Dealogic data }\end{array}$ \\
\hline DCB & $\begin{array}{l}\text { Total domestic currency bond issuance for firm i, country c, year t (millions USD). Source: Own } \\
\text { calculations based on bond-level Dealogic data }\end{array}$ \\
\hline \multirow[t]{2}{*}{ SP } & $\begin{array}{l}\text { Spread between local interest rate and the cost of foreign borrowing. In most cases, the local interest } \\
\text { rate is proxied by the deposit rate. However, if the local money market rate is higher than the local } \\
\text { deposit rate we use the local money market rate. The cost of foreign borrowing is normally proxied } \\
\text { by the sovereign yield in USD. However, if the US interest rate on BAA rated bonds is lower than } \\
\text { the sovereign yield, we use the BAA yield. Source: Local deposit rate is from the World Bank's } \\
\text { World Development Indicators. The BAA yield is from the FRED database and sovereign yields are } \\
\text { from Bloomberg }\end{array}$ \\
\hline & $\begin{array}{l}\mathrm{S} \text { is measured in percentage points. We rescale the spread so that its mean value is zero. Country } \\
\text { c, year t. Source: }\end{array}$ \\
\hline CTI & $\begin{array}{l}\text { Carry trade index. This is an ex ante measure of the attractiveness of carry trades. It is computed } \\
\text { by adding the returns from interest rate differentials to the returns obtained in the foreign exchange } \\
\text { spot market (i.e., it adds the spot return to the interest earned from the long currency position and } \\
\text { subtracts the interest owed from the short currency position). Country c, year t. Source: Bloomberg. }\end{array}$ \\
\hline $\bar{K}$ & $\begin{array}{l}\text { Overall index of capital account openness. The index ranges between } 0 \text { (closed capital account) and } \\
1 \text { (open capital account). Country c, year t. Source: Chinn and Ito (2006) and Fernández et al. } \\
(2015) \text {. }\end{array}$ \\
\hline KI & $\begin{array}{l}\text { Index of capital account openness to inflows. The index ranges between } 0 \text { (closed capital account) } \\
\text { and } 1 \text { (open capital account). Country c, year t. Source: Fernández et al. (2015). }\end{array}$ \\
\hline $\mathrm{KO}$ & $\begin{array}{l}\text { Index of capital account openness to outflows. The index ranges between } 0 \text { (closed capital account) } \\
\text { and } 1 \text { (open capital account). Country c, year t. Source: Fernández et al. (2015). }\end{array}$ \\
\hline FD & $\begin{array}{l}\text { Index of financial depth (credit to the private sector over GDP). We rescaled the index to have } \\
\text { mean=0. Country c, year t. Source: World Development Indicators }\end{array}$ \\
\hline $\mathrm{CR}$ & $\begin{array}{l}\text { Index of creditors' rights. We rescaled the index to have mean }=0 \text {. Country c, year t. Source: World } \\
\text { Bank's Doing Business }\end{array}$ \\
\hline Rating & $\begin{array}{l}\text { Numerical code of sovereign credit rating. We followed the common practice of assigning scores } \\
\text { from } 1 \text { to } 21 \text { to the rating categories ( } 21 \text { being the highest quality rating of AAA) and rescaled the } \\
\text { resulting index to range between } 0 \text { and } 1 \text { (Afonso } 2007 \text {, see Powell and Martinez } 2008 \text { and Cavallo } \\
\text { et al. 2013) for a discussion of using a numerical, cardinal scale for ratings versus other techniques. } \\
\text { Country c, year t. Source: S\&P and Moody's }\end{array}$ \\
\hline BIS & $\begin{array}{l}\text { Four definitions: Total liabilities versus BIS reporting banks; Total non-bank liabilities versus BIS } \\
\text { reporting banks; total loans with BIS reporting banks; total loans of BIS reporting banks to the } \\
\text { non-bank sector. Country c, year t. Source: BIS Statistics. }\end{array}$ \\
\hline
\end{tabular}




\section{Table A2: Details Regarding the Sample of Firms Employed in the Regression}

Analysis

This table reports the composition of the sample of firms used in the analysis. The sample includes firms from the 18 emerging economies listed in the table. The analysis is restricted to the largest fifty non-financial, non-foreign listed firms in each country. After the elimination process described in Footnote 2, we are left with a total of 766 firms in the eighteen countries of interest and with available data for the analysis (the total number of firms after eliminating financials and foreign firms is 803 firms). The table reports the number of firms in each country and also the market capitalization of the final sample relative to the total market capitalization of the subsample of non-financial, non-foreign firms. The table also reports the number of firms in the final sample that report at least one bond issued during the period of analysis (2000-14)

\begin{tabular}{lccc}
\hline \hline & All firms in sample & Share of market capitalization & Number of issuers \\
\hline Argentina & 47 & 1.00 & 8 \\
Brazil & 49 & 0.80 & 25 \\
Chile & 46 & 0.93 & 17 \\
Colombia & 26 & 1.00 & 6 \\
Czech Republic & 6 & 1.00 & 1 \\
Hungary & 22 & 1.00 & 1 \\
Indonesia & 47 & 0.81 & 12 \\
Israel & 45 & 0.89 & 4 \\
Malaysia & 45 & 0.82 & 24 \\
Mexico & 43 & 0.97 & 23 \\
Peru & 50 & 1.00 & 8 \\
Philippines & 48 & 0.96 & 13 \\
Poland & 48 & 0.88 & 6 \\
Russia & 48 & 0.96 & 19 \\
South Africa & 49 & 0.89 & 13 \\
South Korea & 50 & 0.67 & 24 \\
Thailand & 47 & 0.82 & 23 \\
Turkey & 50 & 0.88 & 3 \\
\hline Total & 766 & 0.31 & 230 \\
\hline \hline
\end{tabular}




\section{Table A3: Bruno and Shin regression}

This table reports a set of firm-level regressions in which the dependent variable is the log of the ratio between the change in holdings of liquid financial assets and assets at time t- 1 , and the explanatory variables are foreign currency bond issuances scaled by assets at time t-1 (BFX), the demeaned spread between local deposit rate and borrowing costs in the US (SP), two definition of capital account openness (the Chinn and Ito index in column 3 and the Fernandez et al. index of openness to inflows in column 4), the log of total assets, the log of other source of finance over total assets $(\ln (\mathrm{OTH}))$. All regressions control for firm fixed effects and country-year fixed effects.

\begin{tabular}{|c|c|c|c|c|}
\hline & $(1)$ & $(2)$ & $(3)$ & (4) \\
\hline \multirow[t]{2}{*}{ BFX } & $0.112^{*}$ & $0.126^{*}$ & 0.191 & 0.162 \\
\hline & $(0.0679)$ & $(0.068)$ & $(0.128)$ & $(0.131)$ \\
\hline \multirow[t]{2}{*}{$\mathrm{BFX} \times \mathrm{SP}$} & & 0.0215 & $0.107^{* *}$ & $0.106^{* *}$ \\
\hline & & $(0.018)$ & $(0.044)$ & $(0.045)$ \\
\hline \multirow[t]{2}{*}{$\mathrm{BFX} \times \mathrm{K}$} & & & -0.163 & \\
\hline & & & $(0.215)$ & \\
\hline \multirow[t]{2}{*}{$\mathrm{BFX} \times \mathrm{K} \times \mathrm{SP}$} & & & $-0.167^{* *}$ & \\
\hline & & & $(0.079)$ & \\
\hline \multirow[t]{2}{*}{$\mathrm{BFX} \times \mathrm{KI}$} & & & & -0.0555 \\
\hline & & & & $(0.228)$ \\
\hline \multirow[t]{2}{*}{$\mathrm{BFX} \times \mathrm{K} \times \mathrm{SP}$} & & & & $-0.127^{* *}$ \\
\hline & & & & $(0.061)$ \\
\hline \multirow[t]{2}{*}{$\ln (\mathrm{TA})$} & $-0.039 * * *$ & $-0.039 * * *$ & $-0.039 * * *$ & $-0.039 * * *$ \\
\hline & $(0.011)$ & $(0.011)$ & $(0.011)$ & $(0.011)$ \\
\hline \multirow[t]{2}{*}{$\mathrm{Ln}(\mathrm{OTH})$} & $0.269^{* * *}$ & $0.269^{* * *}$ & $0.269^{* * *}$ & $0.269 * * *$ \\
\hline & $(0.0896)$ & $(0.0896)$ & $(0.0896)$ & $(0.090)$ \\
\hline N. Obs. & 7,929 & 7,579 & 7,579 & 7,579 \\
\hline N. of Firms & 763 & 763 & 763 & 763 \\
\hline Firm FE & Yes & Yes & Yes & Yes \\
\hline Country year FE & Yes & Yes & Yes & Yes \\
\hline
\end{tabular}

Robust standard errors clustered at the firm level in parenthesis. *** $\mathrm{p}<0.01, * * \mathrm{p}<0.05, * \mathrm{p}<0.1$ 
Table A4: Robustness analysis dropping one country at a time

This table reports the coefficients and standard errors of $\mathrm{FXB}^{*} \mathrm{SP}^{*} \mathrm{KI}$ in a set of regression identical to the model of column 2, Table 5. Each regression drops a country. The last column of the table list the country excluded from the regression.

\begin{tabular}{cll}
\hline \hline Point estimate of FXB*SP*KI & Standard errors & Excluded Country \\
\hline-0.0104 & $0.0050^{* *}$ & Argentina \\
-0.0291 & $0.0091^{* * *}$ & Brazil \\
-0.0111 & $0.0045^{* * *}$ & Chile \\
-0.0121 & $0.0044^{* * *}$ & Colombia \\
-0.0088 & $0.0039^{* *}$ & Czech Republic \\
-0.012 & $0.0044^{* * *}$ & Hungary \\
-0.0118 & $0.0044^{* * *}$ & Indonesia \\
-0.0141 & $0.0044^{* * *}$ & Israel \\
-0.0119 & $0.0045^{* * *}$ & Malaysia \\
-0.01 & $0.0044^{* * *}$ & Mexico \\
-0.0098 & $0.0045^{* *}$ & Peru \\
-0.0125 & $0.0046^{* * *}$ & Philippines \\
-0.0121 & $0.0044^{* * *}$ & Poland \\
-0.013 & $0.0044^{* * *}$ & Russia \\
-0.0121 & $0.0044^{* * *}$ & South Africa \\
-0.0149 & $0.0051^{* * *}$ & South Korea \\
-0.0133 & $0.0045^{* * *}$ & Thailand \\
-0.0129 & $0.0043^{* * *}$ & Turkey \\
\hline \hline
\end{tabular}

Robust standard errors clustered at the firm level in parenthesis.

*** $\mathrm{p}<0.01, * * \mathrm{p}<0.05,{ }^{*} \mathrm{p}<0.1$ 


\section{Table A5: Different Periods}

This table reports a set of firm-level regressions in which the dependent variable is the log of the ratio between holdings of liquid financial assets and sales, and the explanatory variables are foreign currency bond issuances (FXB, defined as $\ln (1+$ issuances/sales)), the demeaned spread between local deposit rate and borrowing costs in the US (SP), the Fernández et al. index of capital account openness (K), the Fernández et al. index of capital account openness to inflows (KI). All regressions control for the log of total debt over sales, the log of total sales, leverage, firm fixed effects, and country-year fixed effects. Columns 1 and 2 focus on the 2007-2014 period and columns 3 and 4 on the 2000-2006 period.

\begin{tabular}{|c|c|c|c|c|}
\hline & (1) & $(2)$ & $(3)$ & $(4)$ \\
\hline \multirow[t]{2}{*}{ FXB } & 0.026 & 0.018 & 0.032 & 0.026 \\
\hline & $(0.017)$ & $(0.017)$ & $(0.021)$ & $(0.022)$ \\
\hline \multirow[t]{2}{*}{$\mathrm{FXB} \times \mathrm{SP}$} & $0.008^{*}$ & $0.011^{* * *}$ & $0.008^{*}$ & $0.008^{*}$ \\
\hline & $(0.004)$ & $(0.004)$ & $(0.004)$ & $(0.004)$ \\
\hline \multirow[t]{2}{*}{$\mathrm{FXB} \times \mathrm{K}$} & -0.011 & & -0.027 & \\
\hline & $(0.038)$ & & $(0.037)$ & \\
\hline \multirow[t]{2}{*}{$\mathrm{FXB} \times \mathrm{SP} \times \mathrm{K}$} & -0.013 & & $-0.015^{* *}$ & \\
\hline & $(0.010)$ & & $(0.007)$ & \\
\hline \multirow[t]{2}{*}{$\mathrm{FXB} \times \mathrm{KI}$} & & 0.003 & & -0.01 \\
\hline & & $(0.032)$ & & $(0.037)$ \\
\hline \multirow[t]{2}{*}{$\mathrm{FXB} \times \mathrm{SP} \times \mathrm{KI}$} & & $-0.017^{* *}$ & & $-0.012^{* *}$ \\
\hline & & $(0.007)$ & & $(0.006)$ \\
\hline N. Obs. & 5,109 & 5,109 & 3,132 & 3,132 \\
\hline N. of Firms & 756 & 756 & 570 & 570 \\
\hline Firm FE & Yes & Yes & Yes & Yes \\
\hline Country year FE & Yes & Yes & Yes & Yes \\
\hline Period & $2007-2014$ & $2007-2014$ & $2000-2006$ & $2000-2006$ \\
\hline
\end{tabular}




\section{Table A6: Effect at Time $\mathbf{t}+\mathbf{1}$}

This table reports a set of firm-level regressions in which the dependent variable is the log of the ratio between holdings of liquid financial assets and sales, and the explanatory variables are foreign currency bond issuances (FXB, defined as $\ln (1+$ issuances/sales $))$, the demeaned spread between local deposit rate and borrowing costs in the US (SP), the Fernández et al. index of capital account openness (K), the Fernández et al. index of capital account openness to inflows (KI), the log of total debt over sales, the log of total sales, and leverage. All regressions control for firm fixed effects and country-year fixed effects. In columns 1 and 2, all the explanatory variables are lagged, in columns 3 and 4 only FXB is lagged.

\begin{tabular}{|c|c|c|c|c|}
\hline & $(1)$ & $(2)$ & (3) & (4) \\
\hline \multirow[t]{2}{*}{ FXB } & -0.087 & -0.354 & 0.149 & -0.135 \\
\hline & $(0.451)$ & $(0.481)$ & $(0.429)$ & $(0.471)$ \\
\hline \multirow[t]{2}{*}{$\mathrm{FXB} \times \mathrm{SP}$} & $0.385^{* * *}$ & $0.428^{* * *}$ & $0.367^{* * *}$ & $0.377^{* * *}$ \\
\hline & $(0.137)$ & $(0.153)$ & $(0.129)$ & $(0.136)$ \\
\hline \multirow[t]{2}{*}{$\mathrm{FXB} \times \mathrm{K}$} & 0.309 & & -0.190 & \\
\hline & $(0.998)$ & & $(1.002)$ & \\
\hline \multirow[t]{2}{*}{$\mathrm{FXB} \times \mathrm{K} \times \mathrm{SP}$} & $-0.705^{* * *}$ & & $-0.769^{* * *}$ & \\
\hline & $(0.253)$ & & $(0.244)$ & \\
\hline \multirow[t]{2}{*}{$\mathrm{FXB} \times \mathrm{KI}$} & & 0.701 & & 0.422 \\
\hline & & $(0.899)$ & & $(0.957)$ \\
\hline \multirow[t]{2}{*}{$\mathrm{FXB} \times \mathrm{K} \times \mathrm{SPI}$} & & $-0.617 * * *$ & & $-0.654^{* * *}$ \\
\hline & & $(0.205)$ & & $(0.206)$ \\
\hline N. Obs. & 7,435 & 7,435 & 7,454 & 7,454 \\
\hline N. of Firms & 745 & 745 & 753 & 753 \\
\hline Firm FE & Yes & Yes & Yes & Yes \\
\hline Country year FE & Yes & Yes & Yes & Yes \\
\hline Lags & All control & are lagged & Only FX & is lagged \\
\hline
\end{tabular}

